\title{
Endogenous Policy Decentralization: Testing the Central Tenet of Economic Federalism
}

\author{
Koleman S. Strumpf \\ University of North Carolina at Chapel Hill
}

Felix Oberholzer-Gee

University of Pennsylvania

\begin{abstract}
The economic theory of federalism is largely built around the premise that more heterogeneous preferences result in more decentralized policy making. Despite its prominence and importance, this central tenet of economic federalism has never been empirically evaluated. This paper presents the first formal test of the link between preference heterogeneity and endogenous policy decentralization using as a case study liquor control in the United States over the period 1934-70. The results are reassuring: States with more heterogeneous preferences are more likely to decentralize liquor control and allow for local government decision making.
\end{abstract}

\section{Introduction}

In most countries with federalist constitutions, there is a secular trend to assign more policy responsibility to the central government. In 1900, the U.S. federal government controlled about one-third of total government expenditure. Today, this share is larger than 50 percent. Similar long-term trends can be observed in most federalist countries. More

We thank Bruno Frey, Michael Haines, Jon Hamilton, Bob Inman, Steven Levitt (the editor), Wallace Oates, Paul Rhode, Roberta Romano, and Joel Waldfogel for comments and assistance. We are particularly indebted to Thomas A. Mroz for his extensive econometric advice. This paper has also benefited from the suggestions of seminar participants at numerous universities.

[Journal of Political Economy, 2002, vol. 110, no. 1]

(C) 2002 by The University of Chicago. All rights reserved. 0022-3808/2002/11001-0008 $\$ 10.00$ 
recently, however, a significant move toward more decentralized political systems appears to be emerging (Oates 1999). In the United Kingdom, the central government shifted some of its power to the new parliament in Scotland and to the assembly in Wales. In the United States, responsibility for welfare policy has been devolved to individual states. This trend toward devolution is even more accentuated in developing and transitional nations (Dillinger 1994).

Economists have long recognized that the case for decentralizing policy making rests in large part on the heterogeneity of preferences. While central governments are presumed to provide a uniform level of public goods and identical regulations for all states, ${ }^{1}$ decentralized decision making is better able to tailor policies to local tastes. This is the logic of Oates' (1972) famous decentralization theorem, which states that, in the absence of spillovers, decentralization is welfare superior to centralized decision making. Most of the economic literature on federalism builds on this important insight (see, e.g., Inman and Rubinfeld 1997; Frey and Eichenberger 1999). But is it really the case that preference heterogeneity leads governments to decentralize policy making? Somewhat surprisingly, the existing literature does not answer this question. To our knowledge, the central tenet of economic federalism has never been tested empirically.

In this paper we attempt to close this gap by developing and testing a positive theory of decentralization in a federalist system. Our focus is the assignment of regulatory responsibility to the various levels of government in a federal hierarchy. The application considered here is liquor control in the United States. In particular, we are concerned with the legality of package sales of liquor. ${ }^{2}$ Following the lifting of prohibition in December 1933, individual states became responsible for regulating the sale of distilled spirits. Certain states decentralized liquor policy by permitting local governments to control the legality of liquor, whereas others chose a centralized, uniform policy for all localities. The objective of our paper is to explain this choice of decentralization or centralization.

We begin by modeling a state legislature's choice of centralizing or decentralizing liquor control. The model allows legislators who oppose the centralized policy to buy votes in favor of decentralization. The theoretical prediction is that decentralization will occur when the minority's distaste for the centralized policy is sufficiently strong. In order to test this theory of endogenous decentralization, information on local tastes is needed. Using a unique panel data set of local liquor policies

\footnotetext{
${ }^{1}$ Besley and Coate (1999) study a model in which the central government can provide districts with different levels of local public goods.

${ }^{2}$ The package sale of liquor in stores is legally distinct from sales by the drink in restaurants and bars.
} 
for the period 1934-70, we produce estimates of such local tastes for all counties in the United States. ${ }^{3}$ We use these tastes to calculate a preference heterogeneity measure for each state and to test the theoretical predictions. The empirical estimates suggest that more heterogeneous states are more likely to decentralize liquor control. The logic underlying the decentralization theorem seems to drive actual policy choices.

By linking preferences to policy making, the paper also highlights the endogeneity of government institutions and policies. Taking explicit account of policy endogeneity can have strong implications for applied microeconomic research (Angeles, Guilkey, and Mroz 1998). For example, the literature that studies the efficacy of alcohol control policies makes use of state-level variation in these policies to discern their effect on drunk driving and motor vehicle fatalities (Chaloupka, Saffer, and Grossman 1993; Kenkel 1993). These studies typically treat the statelevel policies as exogenous. But the unobserved taste for liquor influences both control policies and the number of fatalities, so the resulting estimates are likely to overestimate the efficacy of the policy instruments (Brown, Jewell, and Richer 1996). Some studies have sought to eliminate such bias by including a number of variables that are believed to be proxies for tastes. Ruhm (1996) has criticized this rather ad hoc approach and suggested the use of state fixed effects. While fixed effects (and differences-in-differences estimation) partially control for unobserved heterogeneity in tastes, Besley and Case (1994) show that these techniques completely eliminate bias only if the variables that drive policy are time invariant. As this paper will document, liquor tastes evolve over time. Thus a measure of tastes that captures such changes is a useful addition to fixed effects. Including tastes is one way of controlling for relative taste changes between observational units. In an application at the end of this paper, we show that this point is empirically relevant by documenting a negative bias in the estimated price elasticity of liquor consumption when taste dynamics are ignored.

State liquor control is a suitable case study for suggesting general models of endogenous policies because it provides the rare opportunity to study both the origin and the evolution of an institution, the choice of centralized or decentralized liquor control.

\footnotetext{
${ }^{3}$ Our econometric strategy is based on the presumption that the unobserved local tastes determine local liquor policies, which are set in local elections in decentralized states. Linking the local liquor policies to exogenous local characteristics such as demographics and religious affiliation allows us to estimate local tastes for all counties.
} 


\section{Historical Background}

By the time Congress initiated repeal of the Prohibition Act in 1933, it had become apparent that the federal public policy toward liquor had failed miserably (Kyvig 1979). A majority of the public perceived national prohibition as futile and promoting organized crime (Gebhart 1932). In 1930, half of all new federal prisoners were jailed on prohibitionrelated crimes (Wooddy 1934). The Democratic Party advocated repeal of prohibition in its 1932 platform. Franklin Roosevelt's subsequent victory was widely perceived as a mandate for repeal (Dobyns 1940; Munger and Schaller 1997).

The repeal of national prohibition, however, did not imply a return to the laissez-faire policies of earlier times. Antiliquor groups such as Protestant evangelical denominations and the Social Reform movement continued to advocate strict liquor control and even prohibition. Many Protestant churches and smaller, more fundamentalist congregations believed that liquor consumption was responsible for sinful acts or that drinking represented a sin in itself. The most vocal prohibition lobby, the Anti-saloon League, was largely associated with Baptists, Methodists, and Presbyterians. Lutherans and Catholics, on the other hand, did not support the league (Odegard 1928).

But even outside these groups with strong convictions regarding the social cost of drinking, there was a consensus that strict regulation was needed to prevent the disorderly conduct associated with the preprohibition saloon. Federal legislators sought to achieve this goal by making states responsible for liquor control. Prior to prohibition, this responsibility had been placed almost exclusively in the hands of local officials. The resulting myriad of local rules was now to be replaced with statelevel regulation that limited consumption externalities (Harrison and Laine 1936). Subsequently, all states rewrote their liquor control statutes. While seven states initially prohibited the sale of package liquor, ${ }^{4}$ the remaining states permitted it (see figs. 1-3 for the state liquor control status). Among the nonprohibition states, 20 (and eventually 34) states allowed counties and sometimes municipalities or towns to adopt their own liquor policy. In these states, communities were able to decide in local option elections if they wanted to permit the package sale of liquor. From 1934 to 1939, a total of 5,140 such elections took place. Until 1970 , typically hundreds of elections were held in every year. Local option elections led to dramatic changes in the number of people who could purchase liquor in their home community (see figs. 4-8 for wet and dry counties).

Right after prohibition, 37.7 percent of the population lived in areas

\footnotetext{
${ }^{4}$ The prohibition states were Alabama, Georgia, Kansas, Mississippi, North Dakota, Oklahoma, and Tennessee.
} 


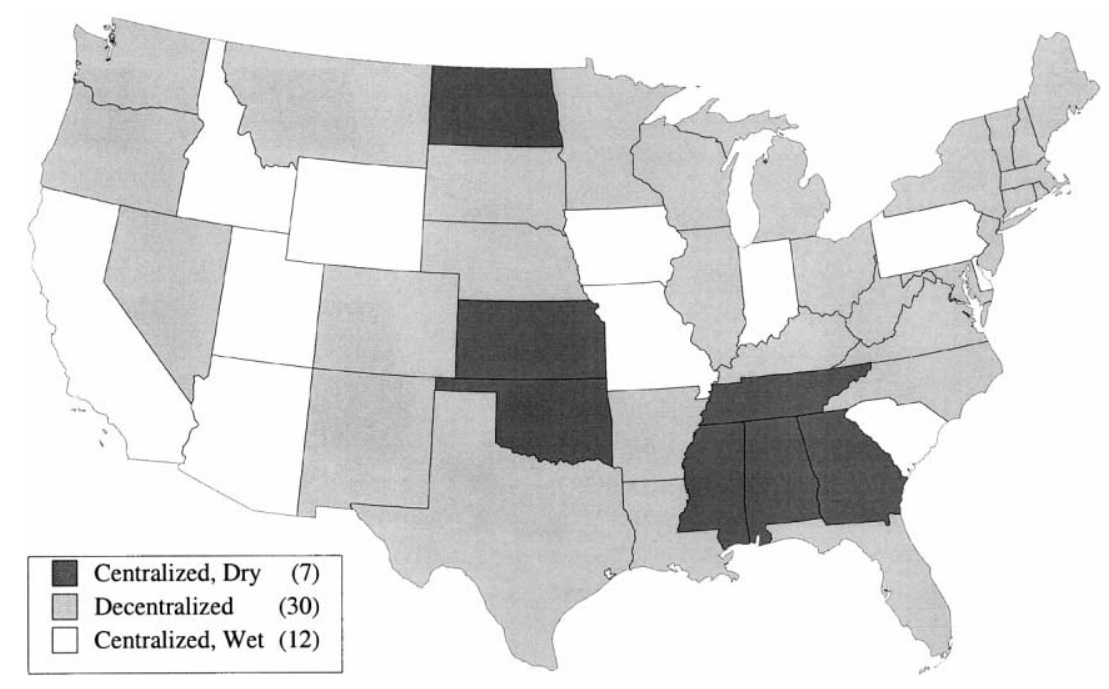

Fig. 1.-1935 state liquor control status

that prohibited the sale of distilled spirits. By 1940, this share had decreased to 18.3 percent. After a slight rise during the World War II period, the population share of prohibition areas steadily declined to about 6 percent in 1970. While some of these changes resulted when states lifted centralized prohibitions, there were also large changes in decentralized states. For example, between 1940 and 1970 the population share of prohibition areas fell from 73.5 percent to 11.0 percent in North Carolina and increased from 14.6 percent to 39.3 percent in Arkansas (Distilled Spirits Institute 1970). With this historical information as a background, we now develop a theoretical model of policy decentralization that will allow us to understand the link between citizen preferences and liquor regulation.

\section{A Model of Policy Decentralization}

Consider a legislature that has $N$ members, each of whom represents a local district. The legislature must decide on a particular policy. It first determines whether to centralize or decentralize policy making. The centralization decision will be denoted by the variable $C \in\{0,1\}$, where $C=1$ is centralization and $C=0$ is decentralization. With decentralized decision making, each local district picks its own policy from a binary choice set $P \in\{-1,1\}$. With centralized decision making, the legislature chooses a uniform policy for all districts from the same set 


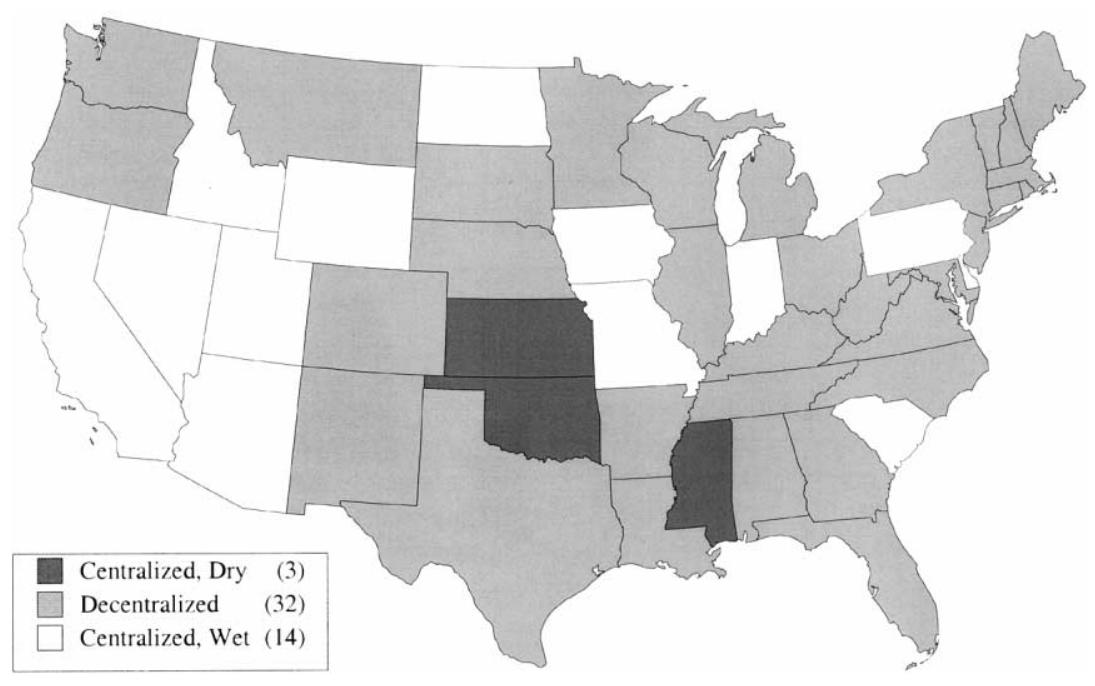

FIG. 2.-1940 state liquor control status

$P$. In our particular application, $P=1$ corresponds to legalizing the package sale of liquor ("wet") and $P=-1$ corresponds to prohibiting the sale of liquor ("dry").

Let $t_{i} \in(-\infty, \infty)$ represent the policy preference of the decisive voter in member $i$ 's district. ${ }^{5}$ With $t_{i} \geq 0$, the decisive voter is wet, which implies that the district will choose to legalize liquor under decentralization. If $t_{i}<0$, the district will be dry under decentralization. Member $i$ 's utility depends on the liquor policy $P_{i}$ that is effective in his district and on the legislature's choice of centralization or decentralization. We write his utility as

$$
U(P, C)=P_{i} t_{i}+C b
$$

The first term in (1) indicates that member $i$ is rewarded when the policy in his district conforms to the preferences of the decisive voter. The member's reward increases when his decisive voter feels more strongly about liquor. Conversely, member $i$ 's utility is reduced if the policy in his district conflicts with the interests of the decisive voter. The second term in (1) indicates that centralized decision making gives each member a relative benefit $b>0$ compared to decentralization. We think of the benefits of centralization as the interest group contributions that the member will receive only when the policy is determined at the

${ }^{5}$ If local policies are set by majority rule, the median voter would be decisive. 


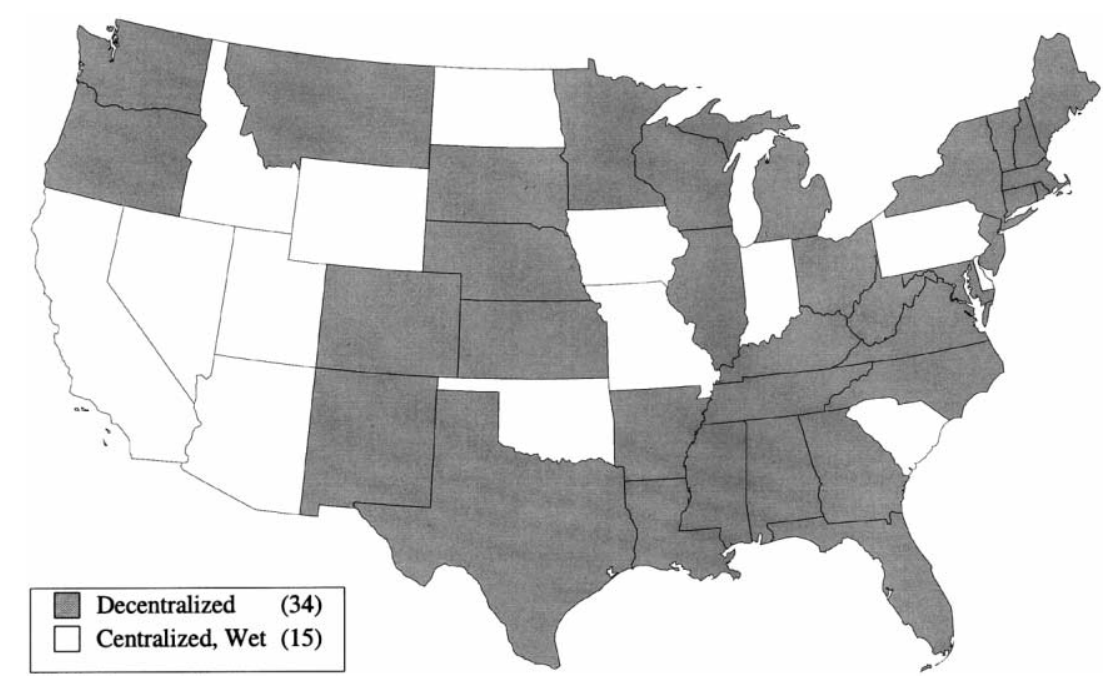

FIG. 3.-1970 state liquor control status

central level. Under decentralization, interest groups will devote their resources to local districts in which liquor policy is actually set. Under centralization, the legislators will receive these contributions because they set liquor policy (for evidence, see Hoover [1999]). ${ }^{6}$

All members are allowed to sell their votes to any other member. The resulting transfer payments can be thought of as actual cash payments ("bribes") or vote trades, which are beneficial to the recipient and costly to the donor. A member will sell or buy votes only if this does not diminish his utility. We shall ignore time consistency issues and presume that the vote sales are enforceable. Given our assumptions, policy making will be decentralized if the tastes of the decisive voters in the minority districts are sufficiently extreme. This result is summarized in the following proposition.

Proposition. Let the set of members with $t_{i} \geq 0$ be denoted as $W$ (for wet) and the set with $t_{i}<0$ denoted as $D$ (for dry). (a) When $N^{-1} \min \left[\sum_{i \in D}\left|t_{i}\right|, \sum_{i \in W} t_{i}\right] \geq b / 2$, the legislature picks $C=0$. (b) When $N^{-1} \min \left[\sum_{i \in D}\left|t_{i}\right|, \quad \sum_{i \in W} t_{i}\right]<b / 2$, the legislature picks $C=1$. When $\sum_{i} t_{i} \geq 0$, the legislature selects $P=1$; otherwise it selects $P=0$.

\footnotetext{
${ }^{6}$ It is of course possible to think of other benefits of centralization such as a reduction of negative externalities or returns to scale in decision making or law enforcement.
} 


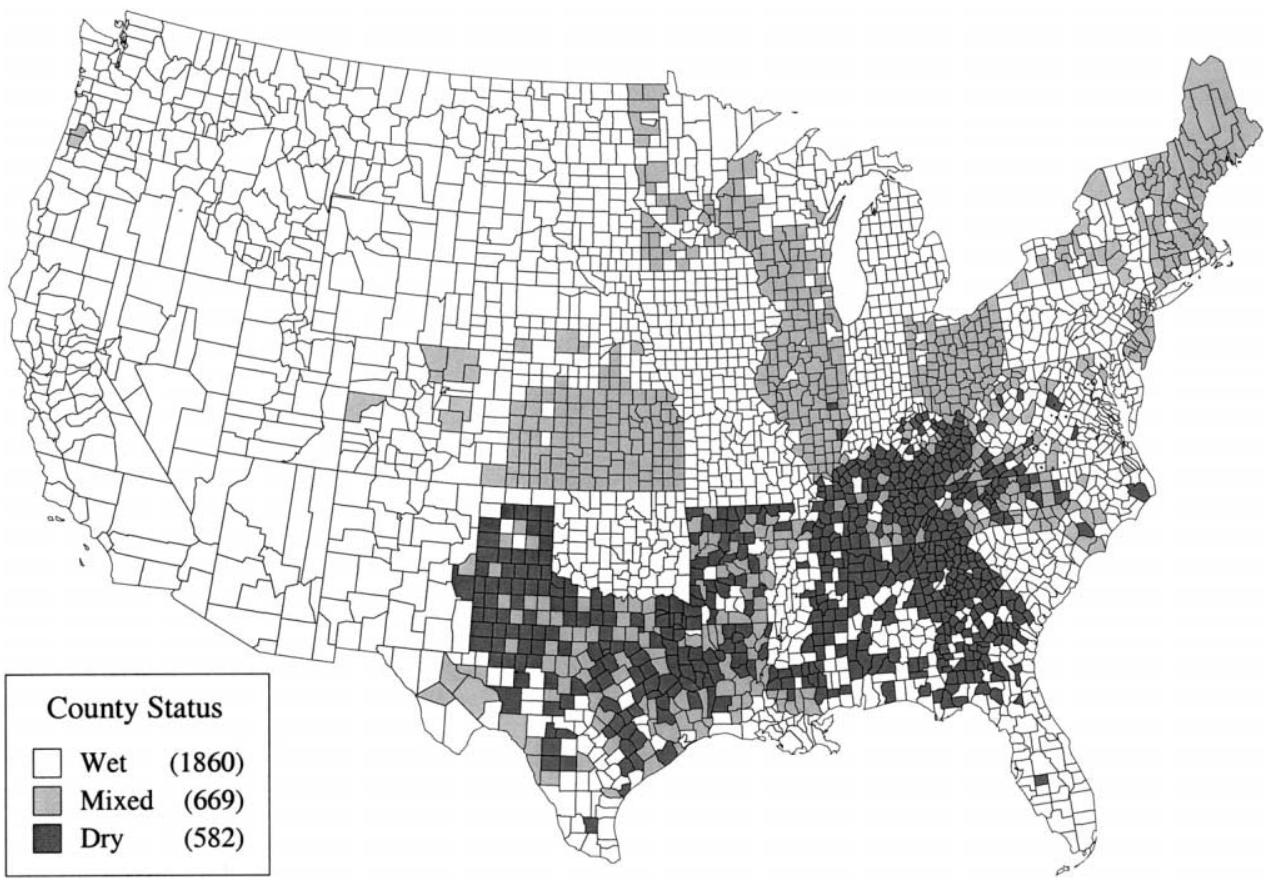

FIG. 4.-Wet and dry counties in 1935 


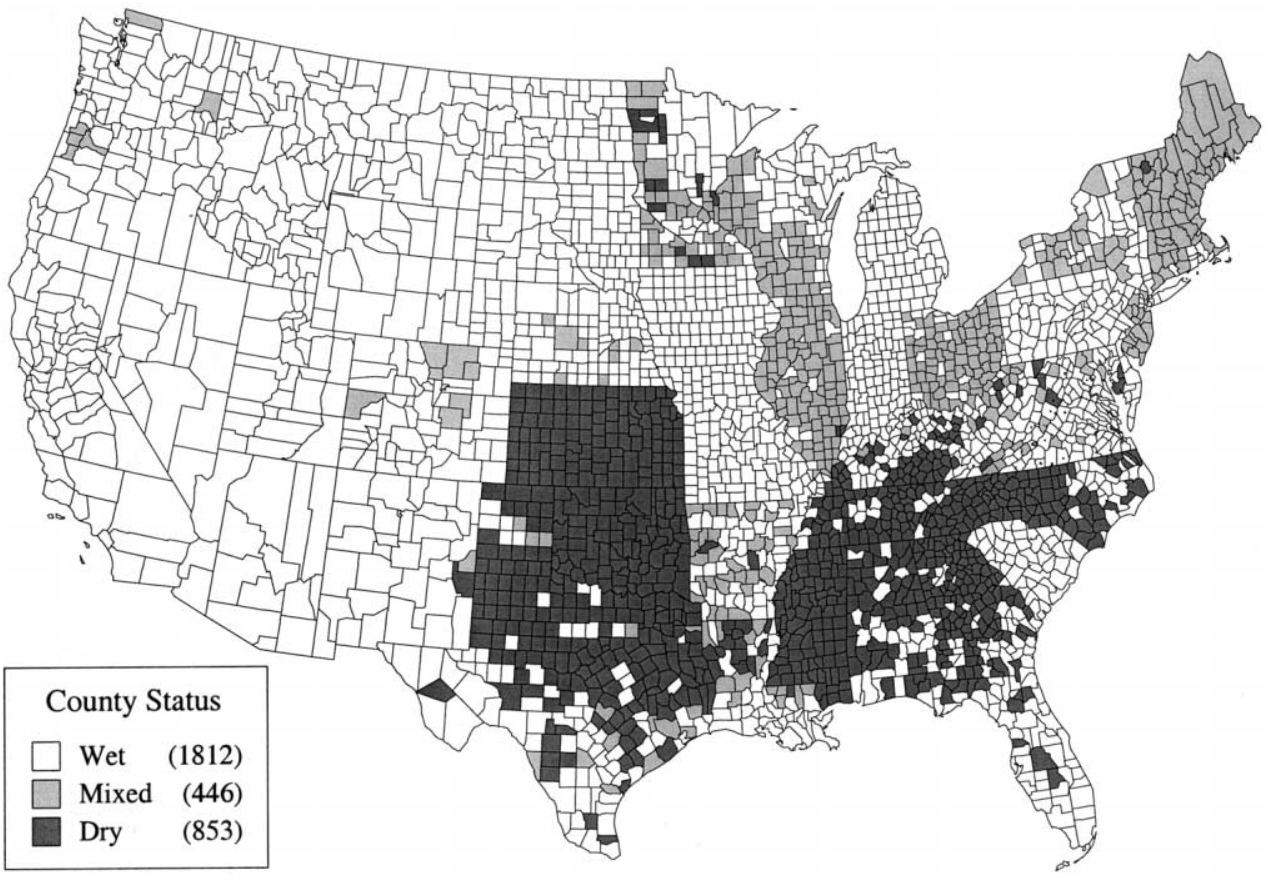

FIG. 5.-Wet and dry counties in 1940 


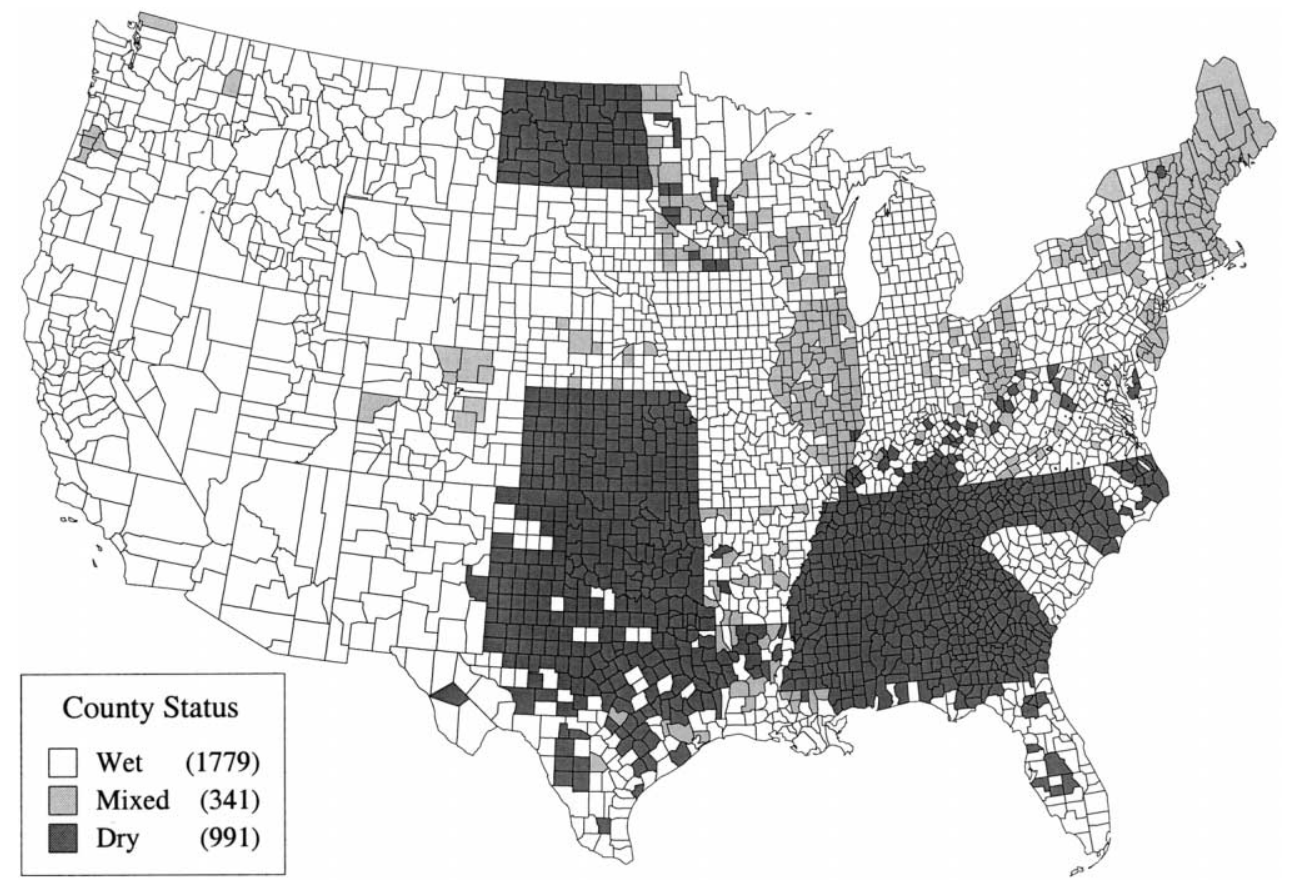

FIG. 6.-Wet and dry counties in 1950 


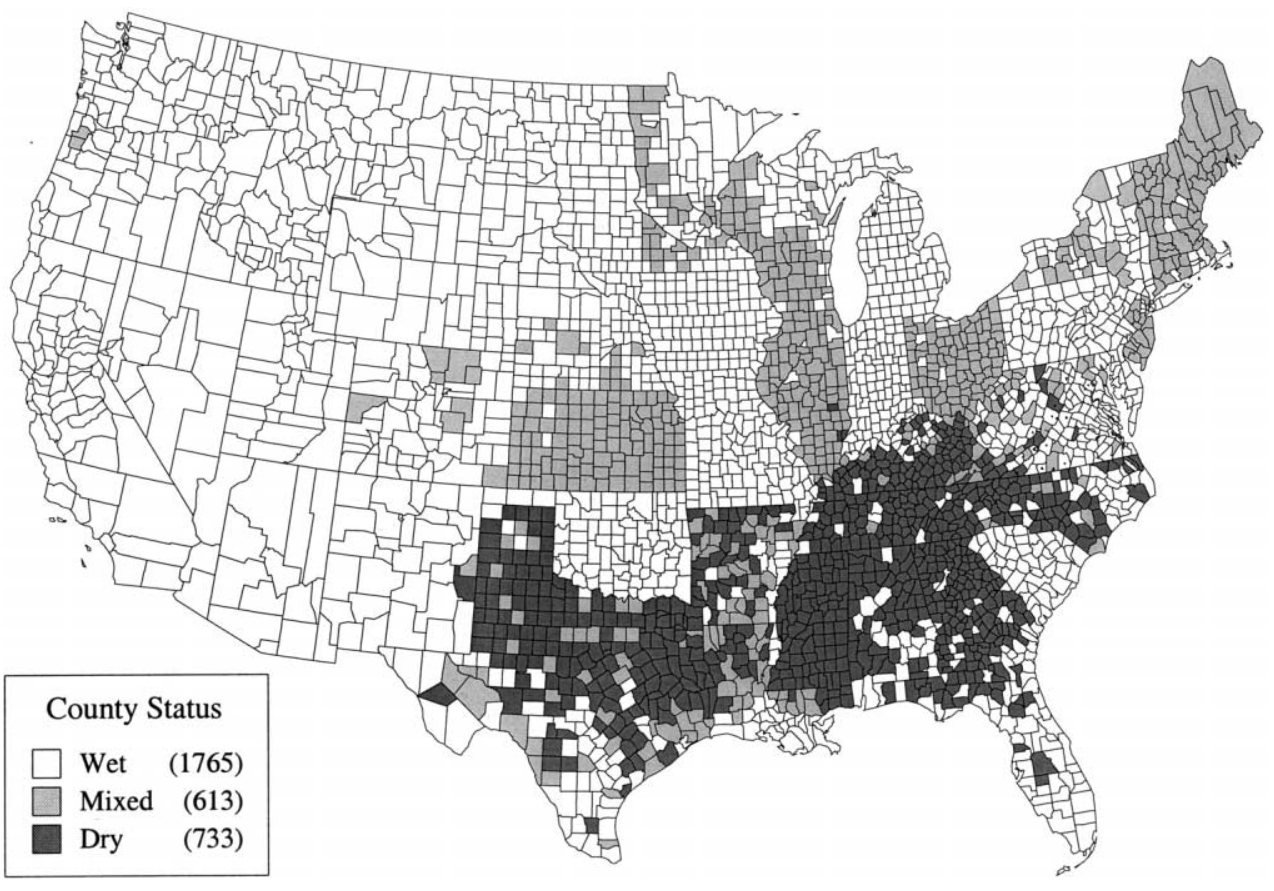

FIG. 7.-Wet and dry counties in 1960 


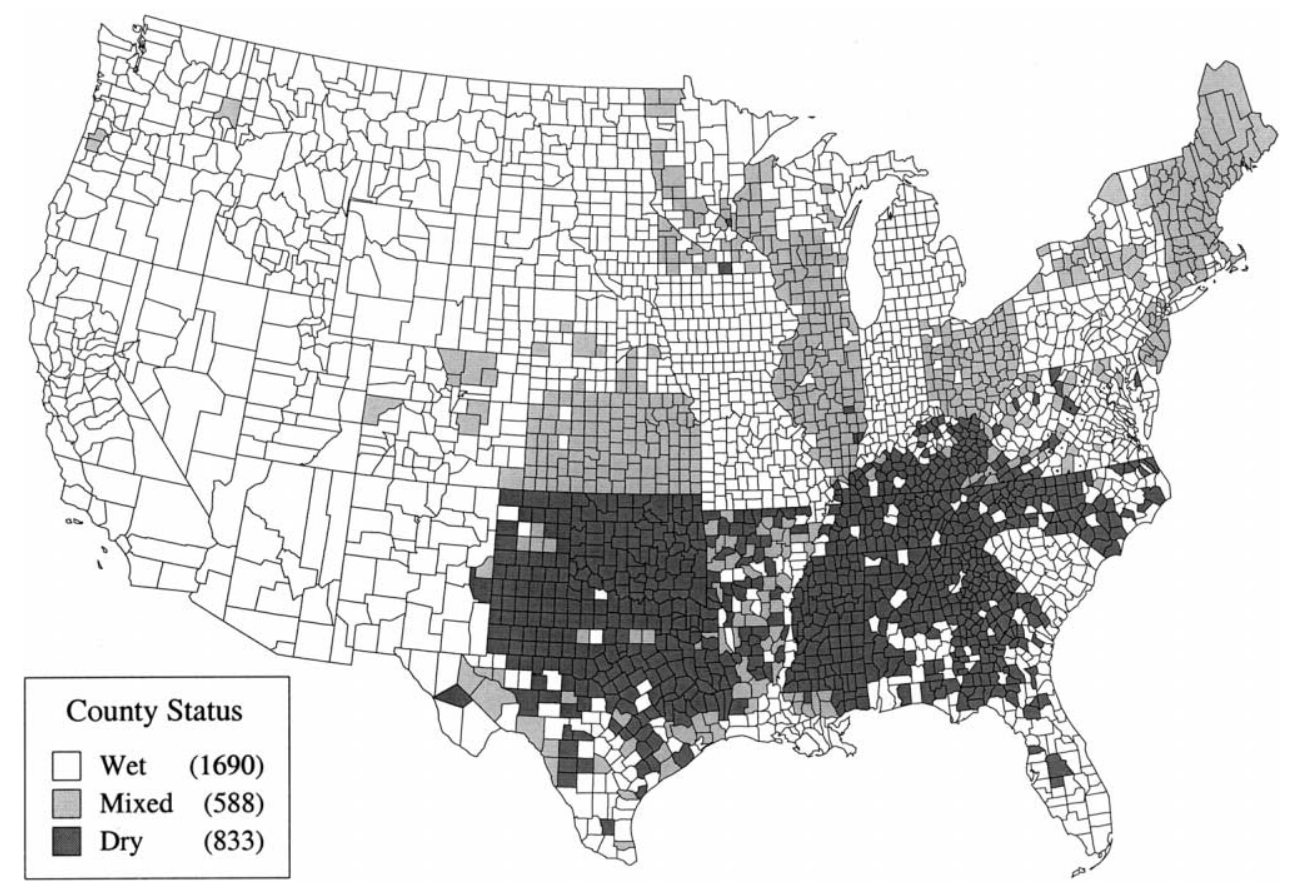

FIG. 8.-Wet and dry counties in 1970 
Proof. See the Appendix. ${ }^{7}$

The first result states that the choice between centralization $(C=1)$ and decentralization $(C=0)$ is determined by the relative size of the centralization benefit and by the tastes of decisive voters from minority districts (the wets in a predominantly dry state and vice versa). The intuition for this result is straightforward. Decentralization has both costs and benefits. The cost is that all members in the legislature lose the centralization benefit, which amounts to $N b$. The benefit of decentralization is the ability of minority districts to avoid an unfavorable policy outcome. Each minority member's utility increases by $2 P_{i} t_{i}$ if his district is allowed to choose its preferred policy outcome. The more extreme the minority preferences, the larger their gain from decentralized policy making. Result $a$ in the proposition simply states that decentralization will occur if the total benefits for minority members, $\min \left[\sum_{i \in D}\left|2 t_{i}\right|, \sum_{i \in W} 2 t_{i}\right]$, exceed the cost to the legislature, $N b$. It might be surprising that the tastes of the majority do not appear in the condition for decentralization. To see why, note that members from majority districts get their preferred policy outcome under either centralization or decentralization. Thus, with decentralization, majority members have to be compensated only for the loss of $b$ and not for a less preferred policy outcome.

The second result states that if centralization is selected, the choice between the two policy outcomes $P=-1$ and $P=1$ is determined by the mean taste of all decisive voters, $\sum_{i} t_{i}$. When this sum is positive, the members supporting $P=1$ can always gain majority support for $P=$ 1 using a suitably large transfer. Notice that numerical majorities are irrelevant to both of these decisions. With vote trading, members whose decisive voter has strong preferences will pay a large transfer to ensure that his preferred policy is selected.

Three aspects of this model deserve closer attention. First, it is important for our result that the decisive voters care only about outcomes and not about legislative processes or a legislator's intentions. A wet voter does not care if he has access to liquor as a result of a centralized wet policy or a local law that permits him to drink. Access to liquor in his district is all that he cares about. Similarly, we assume that the voter will punish his representative for not being able to purchase liquor even if the legislator voted against a centralized dry law. It is the legislative outcome that matters, not the intentions of the legislator.

Second, our model disregards strategic interaction between districts. One could argue that the cost of legalizing liquor, such as the exter-

\footnotetext{
${ }^{7}$ We adopt the convention that $C=0$ is selected in result $a$ when $N^{-1} \min \left[\sum_{i \in D}\left|t_{i}\right|, \sum_{i \in W} t_{i}\right]=b / 2$ and that $C=1, P=1$ is selected in result $b$ when $\sum_{i} t_{i}=0$.
} 
nalities of drunk driving on local roads, may be influenced by the policies of nearby districts. Unfortunately, almost all game-theoretic models of strategic interaction will exhibit multiple equilibria and so do not have sharp empirical implications. ${ }^{8}$ For this reason, we neglect issues of strategic interaction at this stage. However, we shall carefully control for strategic interaction between the districts in our empirical work (see Sec. IVB).

Third, our model ignores the possibility of "moral externalities." It is conceivable that dry voters prefer to ban sales in all districts because they oppose drinking for moral reasons. These voters may oppose decentralization because they are worse off if other individuals drink. Similarly, wet voters may be opposed to restricting the sale of liquor in any district if they feel that such restrictions impair the way of life that is typical for members of their group. While we acknowledge such possibilities, they do not change our basic reasoning that a necessary condition for decentralization is preference heterogeneity.

\section{Empirical Specification and Econometric Issues}

\section{A. Empirical Specification}

The model in the previous section suggests that we shall observe decentralization if the tastes of minority decisive voters are extreme enough so that their representatives in the legislature are willing to "buy" decentralization. Alternatively, if policy making is centralized, liquor will be legalized if this is beneficial to the mean decisive voter. To test the theory, we need information on tastes for liquor of the decisive voter in every district. These tastes are unobserved, but for all decentralized states we know which districts permit the sale of liquor and which ones do not. Observing local liquor policy is useful because it conveys some information about the tastes of the decisive voter. Namely, where liquor is legal, his tastes satisfy $t_{i} \geq 0$. Where it is prohibited, we have $t_{i}<0$. It is worth stressing that, for the purposes of testing our theory, the decisive voter's taste is a sufficient statistic for a local district's taste distribution. That is, within-district taste heterogeneity plays no role in our model, and we shall not estimate distributions of local tastes.

Our empirical strategy then proceeds in two steps. At the first stage, we estimate the tastes of the decisive voter in each district $i$. We assume

\footnotetext{
${ }^{8}$ To see this, assume that policies are strategic complements (the net advantage of policy $P=1$ is increased if a neighbor uses that policy) and that there are two districts whose decisive voters have moderate preferences. There will typically be three equilibria in this case: both districts select $P_{i}=1$, both districts select $P_{i}=-1$, and both districts mix over the two policies.
} 
that these tastes are determined by a linear combination of some observable characteristics $X_{i}$ and an unobserved component $u_{i}$ :

$$
t_{i}=X_{i} \beta+u_{i}
$$

Since liquor sales are legalized in a decentralized district $i$ when $t_{i} \geq 0$ and prohibited otherwise, $\beta$ may be estimated from decentralized districts using a probit (presuming that the unobserved $u_{i}$ has a standard normal distribution). The parameter estimates have the usual interpretation. For example, we shall be able to determine the increased probability of having a wet policy if a district's population share of Catholics grows by 10 percent.

While equation (2) is estimated using only decentralized districts, the resulting $\hat{\beta}$ can be used to fit the expected taste, $E\left(t_{i}\right)=X_{i} \hat{\beta}$, for all districts because the $X_{i}$ are always observed. That is, knowing how the population share of Catholics and other observed covariates relates to the likelihood of adopting a wet policy, we are able to simulate what districts in centralized states would have done had they been granted the right to choose their own liquor policy.

Once we have estimates of tastes for all the districts, we proceed to test the theory. Is it the case that more heterogeneous preferences lead to policy decentralization? We presume that the decentralization decision in state $S$ is based on the factors discussed in the theoretical model and on an unobserved component $e_{1}$ :

$$
\begin{aligned}
D_{S}^{*}= & \alpha_{1} b_{S}+\alpha_{2} N_{S}^{-1} \min \left[\sum_{i \in D_{S}}\left|E\left(t_{i}\right)\right|, \sum_{i \in W_{S}}\left|E\left(t_{i}\right)\right|\right] \\
& +\alpha_{3} I\left(\sum_{i \in S} E\left(t_{i}\right)>0\right)+e_{1 S} .
\end{aligned}
$$

A state will select decentralization $\left(C_{S}=0\right)$ if $D_{S}^{*} \geq 0$. The theoretical model has predictions about the signs of the parameters $\alpha$. When the benefits $b_{S}$ of centralized decision making are larger, decentralization should be less likely. Hence we expect $\alpha_{1}<0$. The expression $N_{S}^{-1} \min \left[\sum_{i \in D_{S}}\left|E\left(t_{i}\right)\right|, \sum_{i \in W_{S}}\left|E\left(t_{i}\right)\right|\right]$ is a measure of the minority members' willingness to pay for decentralization. It is greater if the minority's tastes are more extreme. Thus the theory predicts $\alpha_{2}>0$. The expression $I\left(\sum_{i \in S} E\left(t_{i}\right)>0\right)$ is an indicator function denoting a state's mean taste. If the theory is correct, the mean taste will not influence the decentralization decision, $\alpha_{3}=0$.

Given that the legislature decides to adopt a centralized policy 
$\left(C_{S}=1\right.$ or $\left.D_{S}^{*}<0\right)$, the attractiveness of a uniform wet policy is based on the factors in the model and an unobserved component $e_{2 s}$ :

$$
\begin{aligned}
P_{S}^{*} \mid\left(C_{S}=1\right)= & \lambda_{1} b_{S}+\lambda_{2} N_{S}^{-1} \min \left[\sum_{i \in D_{S}}\left|E\left(t_{i}\right)\right|, \sum_{i \in W_{S}}\left|E\left(t_{i}\right)\right|\right] \\
& +\lambda_{3} I\left(\sum_{i \in S} E\left(t_{i}\right)>0\right)+e_{2 S} .
\end{aligned}
$$

A centralized state will have a wet policy $\left(P_{S}=1\right)$ if $P_{S}^{*} \geq 0$. Under our theory, this decision will be determined by a state's mean taste. Thus we expect $\lambda_{3}>0$. In contrast, the size of the centralization benefit and the willingness of the minority to buy decentralization will not matter: $\lambda_{1}, \lambda_{2}=0$. We shall estimate (3) and (4) as a sequence of probits using state data. This requires that the unobserved components $e_{1 S}$ and $e_{25}$ have independent standard normal distributions.

\section{B. Econometric Issues}

There are three econometric issues with our approach: (i) the role of strategic interaction between districts and the spatial correlation of errors, (ii) the possibility of sample selection in our first-stage procedure, and (iii) the appropriate standard errors for our generated regressors in the second stage. We shall address each of these topics in turn.

i. As mentioned previously, it is possible that neighboring districts in decentralized states influence each other's liquor policy. In this case, liquor policies are determined in a Nash equilibrium of "induced tastes," $\tilde{t}_{i}^{*}$, which we assume to be a linear combination of induced and exogenous preferences. In matrix form this means that $\tilde{t}_{i}^{*}=\phi \mathbf{W} \tilde{t}^{*}+t$, where $\mathbf{W}$ is a neighbor-weighting matrix that accounts for direct interaction between contiguous districts, $\phi$ is a parameter $(\phi>0$ indicates policies that are strategic complements and $\phi<0$ indicates strategic substitutes), and $t=X \beta+u$.

We also consider the possibility that the unobserved component of local tastes, $u$ (which we have interpreted as an error term), may be spatially correlated across districts according to $u=\rho \mathbf{W} u+\epsilon$, where $\rho$ is a parameter and $\epsilon$ is a normally distributed error term. When both strategic interaction and spatially correlated errors are considered, the system to be estimated is

$$
\tilde{t}^{*}=\left(\mathbf{I}_{K}-\phi \mathbf{W}\right)^{-1} X \beta+\left(\mathbf{I}_{K}-\phi \mathbf{W}\right)^{-1}\left(\mathbf{I}_{K}-\rho \mathbf{W}\right)^{-1} \epsilon,
$$

where $\mathbf{I}_{K}$ is the $K \times K$ identity matrix and $K$ is the number of districts 
in all states. ${ }^{9}$ A comparison with equation (2) indicates that ignoring the issues highlighted here will result in biased estimates of $\beta$ (and thus biased estimates of tastes). Because of the difficulties of working with nonindependent dependent variables (see Anselin 1988), we rule out indirect interaction between neighbors of neighbors and consider a firstorder Taylor series approximation of (5):

$$
\tilde{t}^{*} \approx\left(\mathbf{I}_{K}+\phi \mathbf{W}\right) X \beta+\left[\mathbf{I}_{K}+(\phi+\rho) \mathbf{W}\right] \epsilon .
$$

Expression (6) is quasi-linear in the parameters and (under the presumption that decentralized district $i$ selects a wet policy if $\tilde{t}_{i}^{*} \geq 0$ ) can be fit to obtain consistent estimates of $\beta, \phi$, and $\rho .^{10}$ At the second stage, when we test for the influence of taste heterogeneity on the likelihood of decentralization, we suppress the influence of $\phi$ and $\rho$ and consider

$$
E(t)=\left(\mathbf{I}_{K}-\hat{\phi} \mathbf{W}\right) E\left(\tilde{t}^{*}\right) \equiv X \hat{\beta} .
$$

ii. The second econometric issue is sample selection in the first-stage estimates. Recall that our strategy is to estimate $\hat{\beta}$ from districts in decentralized states. When the number of districts in a decentralized state is small, the parameter estimates of $\beta$ generally will be biased (proof available on request). The intuition is that being in a decentralized state confers some information about $u_{i}$, the error term in (2). Because the theory predicts that decentralized states have minority groups with strong tastes, we would expect the $t_{i}$ 's for decentralized districts to be far from zero. This means that the error term in (2) should work in the same direction as $X_{i} \beta$. In other words, $E\left(u_{i} \mid X_{i} \beta>0\right)>0$ and $E\left(u_{i} \mid X_{i} \beta<0\right)<0$.

We correct for this sample selection bias by including state fixed effects when estimating (2) or its generalization (6). With a large number of

\footnotetext{
${ }^{9}$ A further complication is that a decentralized district may be influenced by a centralized district, which does not set its own liquor policy. We account for this by including two separate dummies for bordering a centralized wet state or a centralized dry state in the list of covariates. Neither of the two border dummies is included in the calculation of the underlying tastes, $E(t)$, since they do not reflect any exogenous county-level characteristics.

${ }^{10}$ We estimate (6) using a two-step procedure. In the first step we estimate a probit with covariates $X$ and $\mathbf{W} X$, and the resulting parameter, $\beta^{F_{i t}}$, multiplying the $X$ term, is a consistent estimate of $\beta$. In the second step, we estimate a probit with covariates $X$ and (the scalar) $W X \beta^{F_{i t}}$, and the resulting parameters are consistent estimates of $\beta$ and $\phi$. We then modify the procedure outlined in Poirier and Ruud (1988) to estimate $\rho$ and a consistent estimate of the covariance matrix.
} 
districts, the bias will be the same for all districts in a particular state. ${ }^{11}$ Thus including state fixed effects will yield consistent estimates of $\beta .^{12}$ When fitting the expected tastes, $E(t)$, we shall use the mean state fixedeffects parameter for all decentralized states.

iii. The third econometric issue involves the use of generated regressors in the second-stage estimates, (3) and (4). The second-stage standard errors must be modified because the taste regressors are derived from estimated parameters. Unfortunately, the standard correction technique (Pagan 1984) cannot be readily modified for our case because of the nonlinear transformation of the taste distribution. Instead we use bootstrap standard errors (Efron and Tibshirani 1993). We consider 50 replications from the set of states and, on the basis of the resulting sample, estimate both the first and second stages. ${ }^{13}$ The standard deviations of the second-stage parameter estimates across the replications serve as the bootstrap standard errors.

\section{Data}

We compiled the data for this study from several dozen primary sources and some rarely used census records. A detailed listing and discussion of our data sources are contained in Strumpf and Oberholzer-Gee (2000). In this section, we highlight the points that are essential for the analysis.

For the first-stage estimates of local liquor tastes in (2) or (6), our sample consists of observations for the roughly 3,100 U.S. counties in the 48 contiguous states during the period 1934-70 (descriptive statistics for all variables are presented in table 1$).{ }^{14}$ In these estimates, our dependent variable is an indicator for whether the county liquor policy is wet, and this is available on an annual basis. We consider several countylevel variables, $X$, which may influence the taste for liquor. The historical literature on the subject leads us to expect that religious affiliation will

\footnotetext{
${ }^{11}$ The sample selection bias does vary across districts in a state because each district has a different expected taste, $X_{i} \beta$, and hence a different probability of being in the minority group. Another difference is the extent to which a district is "pivotal" in the decentralization decision, a status that is influenced by the distribution of tastes in the remaining districts. Because this distribution varies across districts (since the district in question is excluded), the pivotal status may vary across districts. These differences disappear as the number of districts in the state grows large.

${ }^{12}$ It is crucial that there are a large number of districts per state since fixed effects (as well as the structural parameters) are inconsistent in discrete response models when there are a finite number of observations per unit. The magnitude of this bias in probits is typically less than 10 percent when there are eight observations per unit (see Hsiao 1986).

${ }^{13}$ The reason we sample from states is that the standard errors for which we are trying to obtain appropriate estimates occur in the second stage, where states are the unit of observation.

${ }^{14}$ We exclude counties in Alaska and Hawaii from the sample since they did not become states until 1959.
} 
TABLE 1

Descriptive Statistics

\begin{tabular}{|c|c|c|c|c|}
\hline & Mean & $\begin{array}{l}\text { Standard } \\
\text { Deviation }\end{array}$ & Maximum & Minimum \\
\hline \multicolumn{5}{|c|}{$\begin{array}{l}\text { Proportion wet governments in decentral- } \\
\text { ized states }\end{array}$} \\
\hline Population $\left(\times 10^{5}\right)$ & .505 & 1.799 & 70.365 & .000 \\
\hline \%Urban population & 28.019 & 27.779 & 100.000 & .000 \\
\hline \multicolumn{5}{|l|}{ Population density $\left(\times 10^{3}\right.$ per square } \\
\hline Land area $\left(\times 10^{3}\right.$ square miles $)$ & .960 & 1.311 & 20.175 & .001 \\
\hline$\%$ Male & 50.602 & 2.163 & 82.200 & 37.600 \\
\hline Black & 10.215 & 16.897 & 85.829 & .000 \\
\hline$\%$ Population $\geq 21$ years old & 58.758 & 5.608 & 82.692 & 38.811 \\
\hline$\%$ Married & 65.908 & 4.742 & 81.294 & 29.288 \\
\hline Median income $\left(\times 10^{3} 1970 \$\right)$ & 5.568 & 2.263 & 18.333 & .758 \\
\hline Average wage income $\left(\times 10^{3} 1970 \$\right)$ & 3.539 & 1.338 & 23.121 & .258 \\
\hline$\%$ High school (or more) & 31.541 & 14.111 & 88.200 & .000 \\
\hline$\%$ College (or more) & 5.036 & 3.191 & 38.600 & .000 \\
\hline$\%$ Unemployed & 5.457 & 4.031 & 47.949 & .000 \\
\hline Median home value $\left(\times 10^{3} 1970 \$\right)$ & 8.036 & 4.343 & 58.720 & .000 \\
\hline$\%$ Renter & 42.676 & 13.715 & 100.000 & .000 \\
\hline$\%$ Adventist & .151 & .407 & 9.136 & .000 \\
\hline$\%$ Baptist & 12.875 & 15.684 & 222.630 & .000 \\
\hline$\%$ Calvinist & 3.331 & 3.720 & 66.131 & .000 \\
\hline$\%$ Catholic & 11.007 & 14.999 & 209.930 & .000 \\
\hline$\%$ Episcopalian & .937 & 1.823 & 39.635 & .000 \\
\hline$\%$ Evangelical & .732 & 1.316 & 20.451 & .000 \\
\hline$\%$ Fundamentalist & 2.091 & 3.337 & 43.975 & .000 \\
\hline \%Jewish & .252 & 1.566 & 58.604 & .000 \\
\hline$\%$ Lutheran & 4.996 & 9.709 & 87.750 & .000 \\
\hline$\%$ Mennonite & .091 & .749 & 18.942 & .000 \\
\hline$\%$ Methodist & 8.287 & 6.187 & 69.266 & .000 \\
\hline$\%$ Mormon & 1.596 & 9.788 & 141.620 & .000 \\
\hline$\%$ Pentecostal & .628 & 1.829 & 26.064 & .000 \\
\hline$\%$ Unitarian & .029 & .215 & 11.012 & .000 \\
\hline Proportion decentralized (states) & .680 & .467 & 1.000 & .000 \\
\hline Liquor interest group $\left(\times 10^{3}\right)$ (states) & 1.473 & 1.174 & 7.244 & .125 \\
\hline Centralization ratio (states) & .794 & .296 & 1.793 & .277 \\
\hline $\begin{array}{l}\text { Number governments / population } \\
\qquad\left(\times 10^{3}\right) \text { (states) }\end{array}$ & .507 & .570 & 3.709 & .080 \\
\hline Poole-Rosenthal score (states) & -.090 & .286 & .735 & -.598 \\
\hline Motor vehicles per capita (states) & .366 & .146 & .743 & .091 \\
\hline
\end{tabular}

Note.-Sample: All counties in the 48 contiguous United States for the period 1934-70 (certain variables are at the state level). There are approximately 3,100 such counties, though several mergers occur during the sample. Religious groups exceeding 100 percent of the population occur fewer than 10 times in the sample and were double-checked with original hard copies of the data.

be important. Because the data include several small but closely related denominations, we aggregated the religions into 14 groups on the basis of their attitudes toward alcohol listed in Gründler (1961). Besides religious affiliation, we consider various demographic variables that are based on census records (see the listing in table 1 ). The religion variables are available for three years over our sample period, and all the demographic variables are available on a decennial frequency. 
These county-level variables need to be exogenous in the sense that they reflect voter attitudes toward liquor policy but will not themselves be influenced by the liquor policy selected. We conducted several formal tests and can reasonably assume that our variables are exogenous. ${ }^{15}$ Finally, our first-stage model includes the neighbor-weighting matrix, $\mathbf{W}$, which we use to control for strategic interaction and spatial correlation (see Sec. IVB). Elements of this matrix are one for land-contiguous and decentralized counties and zero otherwise. We then normalize each row by the number of nonzero elements.

Our second-stage estimates, (3) and (4), are based on state-level data. The dependent variables-whether liquor policy is decentralized in the first set of models and whether a centralized state chooses a wet policy in the second set-are available on an annual basis. We use various proxies of the benefit of centralization, $b$. Our preferred measure is the potential strength of liquor retail interests. State legislators may prefer centralization because this allows them to capture contributions from these groups (Smith 1982; Toma 1988). We expect liquor retail interests to influence policy more strongly if these businesses are more profitable and if the industry is more concentrated (Olson 1965). We use the profit retention rate (i.e., one minus the state-level corporate income tax rate) as a proxy for industry profits. As for our measure of industry concentration, it is not possible to directly use the number of liquor establishments in a state because this number is endogenously determined. We use the degree of urbanization as an instrument for the number of liquor establishments. The potential strength of liquor interests is then measured as the profit retention rate divided by the instrumented value for the number of retail liquor businesses. Our alternative measures of $b$ reflect differences in citizen preferences toward centralization. We consider two centralization ratios: state to local government spending and the per capita number of governments in the state. Both measures may reflect tastes toward centralization and implicitly the relative efficacy of the state government. We also use the mean of the house members' Poole-Rosenthal D-NOMINATE scores as a more general measure of ideology (Poole and Rosenthal 1997). The final proxy reflects the neg-

\footnotetext{
${ }^{15}$ County characteristics cannot be considered exogenous if local liquor policies influence them. For example, if Catholics (who like to drink) move to areas that they expect to be wet in the future, the variable \%Catholic would be endogenous. We conduct two formal tests to analyze whether this type of migration presents a problem. The first test checks whether local liquor policy can explain changes in population characteristics between the end of prohibition and various years in our sample. In the second test, we investigate whether changes in population characteristics during our study period are due to changes in local liquor policy. Both tests find significant effects in fewer than 20 percent of all cases. In addition, many of the significant parameters have the "wrong" sign; i.e., we find significant migration to wet counties for groups that do not like to drink. The results suggest that the county covariates that we use can reasonably be considered exogenous to local liquor policies.
} 
ative externality associated with drunk driving. Our measure is the number of motor vehicles registered per capita. ${ }^{16}$ All measures reflect a preference for centralization, except the number of governments and the Poole-Rosenthal scores, which indicate a preference against centralization.

\section{Results}

\section{A. County-Level Taste Parameters}

The first step is to estimate the relationship between local characteristics and local liquor policies. On the basis of the discussion in Section IV, the specification is

$$
\tilde{t}^{*}=X \beta+\phi \mathbf{W} X \beta+\delta I(\text { centralized })+F E_{S}+\omega,
$$

where $\tilde{t}^{*}$ are the (latent) induced tastes of county decisive voters, $X$ are county characteristics, $\mathbf{W} X$ are the characteristics of neighboring counties, $I$ (centralized) are dummies for bordering a wet or dry centralized state, $F E_{S}$ are state fixed effects, and $\omega$ is an error related to the unobserved component of tastes. Under the presumption that decentralized county $i$ selects a wet policy if $\tilde{t}_{i}^{*} \geq 0,(8)$ is estimated on the basis of the observed liquor policies in decentralized counties using a two-step procedure (see n. 10)..$^{17}$

The resulting parameter estimates are presented in table 2. In the interest of flexibility, we make separate estimates for the years 1935, 1940, 1950, 1960, and 1970. Most parameter estimates have a straightforward interpretation. For example, Baptists, Calvinists (which include Presbyterians), and Methodists have significant negative parameters (meaning they are associated with local prohibition), whereas Catholics, Episcopalians, and Lutherans have significant positive parameters (meaning they are associated with legalizing liquor). These results are consistent with the historical literature: the first three religions sup-

\footnotetext{
${ }^{16}$ Note that the number of cars may also proxy for income and for the degree of urbanization.

${ }^{17}$ One complication involves the presence of subcounty liquor policies: In some decentralized states, municipalities within a county are allowed to regulate liquor. We cannot use municipalities as the unit of observation because our covariates are unavailable at the municipal level during our sample. Instead, we presume that each municipality has the same covariate characteristics as its county and that each municipality taste equation has its own independent error term. Under these assumptions, only three modifications are needed to form the likelihood function for (8): (i) each county appears $N_{i}$ times, where $N_{i}$ is the number of governments selecting a liquor policy in county $i$; (ii) for each county, the dependent variables are one for $P_{i}$ observations and zero for the remaining $\left(N_{i}-P_{i}\right)$ observations, where $P_{i}$ is the number of wet governments in county $i$; and (iii) the righthand-side variables are normalized using weights $N_{i}^{-0.5}$. Full details and a proof of our approach are available on request.
} 
TABLE 2

Estimation of County LiQuor Tastes

Dependent Variable: County Permits Package Sale of Liquor (Indicator)

\begin{tabular}{|c|c|c|c|c|c|}
\hline & $\begin{array}{c}1935 \\
(N=1,752)\end{array}$ & $\begin{array}{c}1940 \\
(N=2,084)\end{array}$ & $\begin{array}{c}1950 \\
(N=1,788)\end{array}$ & $\begin{array}{c}1960 \\
(N=1,777)\end{array}$ & $\begin{array}{c}1970 \\
(N=2,322)\end{array}$ \\
\hline \%Adventist & $\begin{array}{l}1.538 \\
(.40)\end{array}$ & $\begin{array}{l}1.022 \\
(.38)\end{array}$ & $\begin{array}{r}-.172 \\
(.20)\end{array}$ & $\begin{array}{c}-.121 \\
(.18)\end{array}$ & $\begin{array}{r}-.181 \\
(.10)\end{array}$ \\
\hline$\%$ Baptist & $\begin{array}{c}-.060 \\
(.01)\end{array}$ & $\begin{array}{c}-.040 \\
(.01)\end{array}$ & $\begin{array}{c}-.032 \\
(.01)\end{array}$ & $\begin{array}{c}-.023 \\
(.01)\end{array}$ & $\begin{array}{c}-.013 \\
(.00)\end{array}$ \\
\hline \%Calvinist & $\begin{array}{c}-.059 \\
(.02)\end{array}$ & $\begin{array}{c}-.067 \\
(.02)\end{array}$ & $\begin{array}{c}-.095 \\
(.02)\end{array}$ & $\begin{array}{c}-.074 \\
(.02)\end{array}$ & $\begin{array}{c}-.016 \\
(.01)\end{array}$ \\
\hline \%Catholic & $\begin{array}{l}.077 \\
(.01)\end{array}$ & $\begin{array}{l}.096 \\
(.01)\end{array}$ & $\begin{array}{l}.082 \\
(.01)\end{array}$ & $\begin{array}{l}.102 \\
(.01)\end{array}$ & $\begin{array}{l}.080 \\
(.00)\end{array}$ \\
\hline \%Episcopalian & $\begin{array}{l}.265 \\
(.05)\end{array}$ & $\begin{array}{l}.196 \\
(.04)\end{array}$ & $\begin{array}{l}.659 \\
(.06)\end{array}$ & $\begin{array}{l}.890 \\
(.07)\end{array}$ & $\begin{array}{l}.666 \\
(.05)\end{array}$ \\
\hline$\%$ Evangelical & $\begin{array}{l}1.001 \\
(.22)\end{array}$ & $\begin{array}{l}.854 \\
(.19)\end{array}$ & $\begin{array}{c}-.006 \\
(.07)\end{array}$ & $\begin{array}{l}.021 \\
(.04)\end{array}$ & $\begin{array}{l}.034 \\
(.02)\end{array}$ \\
\hline$\%$ Fundamentalist & $\begin{array}{c}-.014 \\
(.02)\end{array}$ & $\begin{array}{l}.015 \\
(.02)\end{array}$ & $\begin{array}{c}-.003 \\
(.01)\end{array}$ & $\begin{array}{l}.070 \\
(.02)\end{array}$ & $\begin{array}{l}.037 \\
(.02)\end{array}$ \\
\hline \%Jewish & $\begin{array}{l}.079 \\
(.04)\end{array}$ & $\begin{array}{l}.066 \\
(.04)\end{array}$ & $\begin{array}{l}.345 \\
(.11)\end{array}$ & $\begin{array}{c}-.221 \\
(.11)\end{array}$ & $\begin{array}{c}-.106 \\
(.07)\end{array}$ \\
\hline \%Lutheran & $\begin{array}{l}.029 \\
(.01)\end{array}$ & $\begin{array}{l}.034 \\
(.01)\end{array}$ & $\begin{array}{l}.045 \\
(.01)\end{array}$ & $\begin{array}{l}.088 \\
(.01)\end{array}$ & $\begin{array}{l}.041 \\
(.01)\end{array}$ \\
\hline$\%$ Mennonite & $\begin{array}{l}.367 \\
(.26)\end{array}$ & $\begin{array}{l}.051 \\
(.08)\end{array}$ & $\begin{array}{r}-.007 \\
(.10)\end{array}$ & $\begin{array}{c}-.065 \\
(.06)\end{array}$ & $\begin{array}{r}-.045 \\
(.03)\end{array}$ \\
\hline \% Methodist & $\begin{array}{r}-.111 \\
(.01)\end{array}$ & $\begin{array}{r}-.081 \\
(.01)\end{array}$ & $\begin{array}{c}-.040 \\
(.01)\end{array}$ & $\begin{array}{c}-.023 \\
(.01)\end{array}$ & $\begin{array}{c}-.020 \\
(.01)\end{array}$ \\
\hline$\%$ Pentecostal & $\begin{array}{l}1.035 \\
(.74)\end{array}$ & $\begin{array}{l}.589 \\
(.41)\end{array}$ & $\begin{array}{c}-.200 \\
(.14)\end{array}$ & $\begin{array}{c}-.099 \\
(.03)\end{array}$ & $\begin{array}{c}-.025 \\
(.01)\end{array}$ \\
\hline \%Unitarian & $\begin{array}{l}.021 \\
(.39)\end{array}$ & $\begin{array}{l}.272 \\
(.38)\end{array}$ & $\begin{array}{r}-.021 \\
(.13)\end{array}$ & $\begin{array}{l}.406 \\
(.20)\end{array}$ & $\begin{array}{l}.950 \\
(.37)\end{array}$ \\
\hline Population & $\begin{array}{l}.276 \\
(.10)\end{array}$ & $\begin{array}{l}.301 \\
(.09)\end{array}$ & $\begin{array}{c}-.314 \\
(.19)\end{array}$ & $\begin{array}{l}.524 \\
(.15)\end{array}$ & $\begin{array}{l}.365 \\
(.05)\end{array}$ \\
\hline $\begin{array}{l}\text { \% Urban } \\
\text { population }\end{array}$ & $\begin{array}{l}.024 \\
(.00)\end{array}$ & $\begin{array}{l}.027 \\
(.00)\end{array}$ & $\begin{array}{r}-.002 \\
(.00)\end{array}$ & $\begin{array}{c}-.003 \\
(.00)\end{array}$ & $\begin{array}{r}-.002 \\
(.00)\end{array}$ \\
\hline $\begin{array}{l}\text { Population } \\
\text { density }\end{array}$ & $\begin{array}{c}-.214 \\
(.04)\end{array}$ & $\begin{array}{c}-.178 \\
(.03)\end{array}$ & $\begin{array}{c}-1.774 \\
(.26)\end{array}$ & $\begin{array}{c}-2.134 \\
(.24)\end{array}$ & $\begin{array}{c}-.194 \\
(.04)\end{array}$ \\
\hline Land area & $\begin{array}{l}.547 \\
(.12)\end{array}$ & $\begin{array}{l}.359 \\
(.10)\end{array}$ & $\begin{array}{l}.478 \\
(.10)\end{array}$ & $\begin{array}{l}.014 \\
(.10)\end{array}$ & $\begin{array}{l}.290 \\
(.09)\end{array}$ \\
\hline$\%$ Male & $\begin{array}{l}.322 \\
(.06)\end{array}$ & $\begin{array}{l}.317 \\
(.04)\end{array}$ & $\begin{array}{l}.028 \\
(.04)\end{array}$ & $\begin{array}{c}-.088 \\
(.04)\end{array}$ & $\begin{array}{c}-.114 \\
(.03)\end{array}$ \\
\hline$\%$ Black & $\begin{array}{l}.046 \\
(.01)\end{array}$ & $\begin{array}{l}.044 \\
(.00)\end{array}$ & $\begin{array}{l}.037 \\
(.00)\end{array}$ & $\begin{array}{l}.050 \\
(.01)\end{array}$ & $\begin{array}{l}.039 \\
(.01)\end{array}$ \\
\hline $\begin{array}{l}\text { \%Population } \\
\geq 21 \text { vears old }\end{array}$ & $\begin{array}{l}.114 \\
(.02)\end{array}$ & $\begin{array}{l}.081 \\
(.02)\end{array}$ & $\begin{array}{l}.126 \\
(.02)\end{array}$ & $\begin{array}{l}.017 \\
(.02)\end{array}$ & $\begin{array}{c}-.032 \\
(.01)\end{array}$ \\
\hline$\%$ Married & $\begin{array}{l}.008 \\
(.02)\end{array}$ & $\ldots$ & $\begin{array}{c}-.033 \\
(.02)\end{array}$ & $\begin{array}{c}-.004 \\
(.02)\end{array}$ & $\begin{array}{c}-.035 \\
(.02)\end{array}$ \\
\hline Median income & $\ldots$ & $\cdots$ & $\begin{array}{l}.813 \\
(.09)\end{array}$ & $\begin{array}{l}.973 \\
(.08)\end{array}$ & $\begin{array}{l}.372 \\
(.06)\end{array}$ \\
\hline$\%$ High school & $\begin{array}{l}.030 \\
(.02)\end{array}$ & $\begin{array}{l}.036 \\
(.02)\end{array}$ & $\begin{array}{l}.027 \\
(.01)\end{array}$ & $\begin{array}{l}.004 \\
(.01)\end{array}$ & $\begin{array}{l}.057 \\
(.01)\end{array}$ \\
\hline$\%$ College & $\begin{array}{c}-.098 \\
(.07)\end{array}$ & $\begin{array}{r}-.071 \\
(.06)\end{array}$ & $\begin{array}{r}-.252 \\
(.04)\end{array}$ & $\begin{array}{c}-.153 \\
(.04)\end{array}$ & $\begin{array}{c}-.204 \\
(.02)\end{array}$ \\
\hline \%Unemployed & $\begin{array}{l}.014 \\
(.02)\end{array}$ & $\begin{array}{c}-.020 \\
(.01)\end{array}$ & $\begin{array}{l}.196 \\
(.03)\end{array}$ & $\begin{array}{l}.056 \\
(.02)\end{array}$ & $\begin{array}{l}.053 \\
(.03)\end{array}$ \\
\hline $\begin{array}{l}\text { Median home } \\
\text { value }\end{array}$ & $\begin{array}{r}-.091 \\
(.04)\end{array}$ & $\begin{array}{c}-.098 \\
(.03)\end{array}$ & $\begin{array}{c}-.020 \\
(.03)\end{array}$ & $\begin{array}{c}-.071 \\
(.03)\end{array}$ & $\begin{array}{c}-.063 \\
(.02)\end{array}$ \\
\hline
\end{tabular}


TABLE 2

(Continued)

\begin{tabular}{|c|c|c|c|c|c|}
\hline & $\begin{array}{c}1935 \\
(N=1,752)\end{array}$ & $\begin{array}{c}1940 \\
(N=2,084)\end{array}$ & $\begin{array}{c}1950 \\
(N=1,788)\end{array}$ & $\begin{array}{c}1960 \\
(N=1,777)\end{array}$ & $\begin{array}{c}1970 \\
(N=2,322)\end{array}$ \\
\hline \multirow[t]{2}{*}{$\%$ Renter } & .054 & .028 & .051 & .106 & .078 \\
\hline & $(.01)$ & $(.01)$ & $(.01)$ & $(.01)$ & $(.01)$ \\
\hline \multirow{2}{*}{$\begin{array}{l}I(\text { centralized wet } \\
\text { border })\end{array}$} & -.102 & .014 & -.741 & -.524 & -.564 \\
\hline & $(.16)$ & $(.14)$ & $(.15)$ & $(.14)$ & $(.12)$ \\
\hline \multirow{2}{*}{$\begin{array}{l}I \text { (centralized dry } \\
\quad \text { border })\end{array}$} & -.078 & .438 & .083 & .580 & $\ldots$ \\
\hline & $(.18)$ & $(.21)$ & $(.21)$ & $(.35)$ & \\
\hline \multirow[t]{2}{*}{$\phi$} & .554 & .468 & .358 & .304 & .574 \\
\hline & $(.05)$ & $(.05)$ & $(.04)$ & $(.04)$ & $(.05)$ \\
\hline$\rho$ & -.074 & -.082 & -.088 & -.024 & -.150 \\
\hline \multicolumn{6}{|l|}{ State fixed } \\
\hline effects? & yes & yes & yes & yes & yes \\
\hline \multicolumn{6}{|l|}{$\begin{array}{l}\text { Mean proportion } \\
\text { wet }\end{array}$} \\
\hline governments & .76 & .67 & .58 & .58 & .64 \\
\hline Log likelihood & $-6,584.22$ & $-8,395.03$ & $-7,429.53$ & $-7,187.76$ & $-9,082.50$ \\
\hline
\end{tabular}

NotE.-Sample: Counties in decentralized states. Standard errors are shown in parentheses below the parameter estimates. Estimation techniques are explained in Sec. IVB. Interpolations were used for 1935 census variables (except $\%$ married [1930 data are used], \%high school [1940 data are used], and \%college [1940 data are used]) and 1960 religion variables. Unavailable explanatory variables are \%married (1940) and median income (1930 and 1940). No $I$ (centralized dry border) parameter is estimated in 1970 because there are no centralized dry states in that year. See n. 17 for the treatment of subcounty policies.

ported the liquor prohibition movement and the latter three groups opposed it. Our findings also conform to earlier empirical work. Toma (1988) in her study on liquor licenses, Goff and Anderson (1994) in a paper on senatorial support for repeal, and Hersch and Netter (1989) in work on the rate at which states adopted prohibition in the nineteenth century all find similar effects of religious affiliation. ${ }^{18}$

Several county characteristics have large effects on the propensity to be wet. A one-standard-deviation increase in the following variables changes the probability of being wet by at least 0.15 in all years (when evaluated at mean values): \%Baptist, \%Catholic, \%Episcopalian, population, population density, land area, \%black, median income, and \%renter. For example, in 1935 a one-standard-deviation increase in \% Baptist (\%Catholic) changes the probability of being wet by -0.271 (0.446).

${ }^{18}$ There is also contemporary evidence linking the characteristics here to individual preferences. The General Social Survey (1999) contains information on individual demographics and drinking behavior. Presumably individuals who oppose liquor sales are unlikely to drink, whereas those who favor liquor sales are likely to at least occasionally have a drink. Using General Social Survey data over the period 1972-96, we found a statistically significant relationship between an individual drinking indicator and the following demographic variables: religious affiliation, gender, race, age, marital status, education, and income. In addition, these relationships are in the expected direction; e.g., only 56.0 percent of Baptist respondents $(N=3,448)$ said they drink, whereas 84.3 percent of Catholics $(N=4,008)$ reportedly drink. 
The positive and significant $\phi$ parameter in table 2 suggests that local liquor policies are strategic complements. One explanation is that being surrounded by wet neighbors lowers the cost of being wet, possibly because it decreases the number of drunk drivers from neighboring districts. The small $\rho$ parameter indicates that there are unlikely to be spatially correlated errors. ${ }^{19}$

We checked whether the parameter estimates in table 2 are time varying. After the five years are pooled, it is possible to reject a null of time-invariant parameters even at the 99 percent confidence level. Some variables associated with local prohibition-such as Baptists and Methodists-have parameters that become more positive over time. ${ }^{20}$ This is consistent with the historical record, which shows that such groups become increasingly tolerant of legalizing liquor over our sample period. More generally, the parameter variation suggests that liquor tastes evolve over time, a topic we shall return to later.

To assess the quality of our first-stage estimates, we performed an outof-sample prediction. During the period of our study, five states (Alabama, Georgia, Kansas, Mississippi, and Tennessee) changed from a centralized to a decentralized policy. The estimated tastes allow us to predict county liquor policies, which can be compared with the actual policies that counties in these states chose once they were free to adopt their preferred liquor status. We correctly predict the county policy in 86.9 percent of all cases $(N=510)$. As a comparison, 66.7 percent of these counties actually adopted a dry policy. This reasonably close fit and the consistency of our findings with both the historical and the empirical literature suggest that our parameter estimates capture the most important determinants of local preferences over liquor policy.

\section{B. State Decisions: Testing the Model}

We now turn to our main results. Are we able to predict whether states decentralize liquor control on the basis of the estimated county liquor tastes? Before we turn to the formal tests, it is useful to consider a qualitative comparison. Table 3 presents two measures of within-state taste heterogeneity: the minority group taste measure developed in the theory section, which expresses the minority members' willingness to "buy" decentralization; and the within-state variance of the estimated county tastes, which is a more general measure of taste heterogeneity. Decentralized states tend to have higher values of both measures, suggesting that they have greater taste diversity. The contrast between par-

\footnotetext{
${ }^{19}$ There is no available standard error for $\rho$, which is estimated using a grid search.

${ }^{20}$ It is inappropriate to directly compare parameter values across different samples because of the variance normalization implicit in the estimation procedure. The interpretations in the text involve parameter values relative to the \%black parameter in each year.
} 
TABLE 3

Qualitative Review of Taste Heterogeneity

\begin{tabular}{|c|c|c|c|c|c|}
\hline & 1935 & 1940 & 1950 & 1960 & 1970 \\
\hline & \multicolumn{5}{|c|}{$\begin{array}{l}\text { A. Minority Group Taste Measure, } \\
N^{-1} \min \left[\Sigma_{i \in D}\left|E\left(t_{i}\right)\right|, \Sigma_{i \in W}\left|E\left(t_{i}\right)\right|\right]\end{array}$} \\
\hline Alabama & .000 & .000 & .343 & .381 & .000 \\
\hline California & .026 & .196 & .000 & .000 & .000 \\
\hline Georgia & .000 & .000 & .378 & .180 & .021 \\
\hline Idaho & .000 & .000 & .000 & .000 & .000 \\
\hline Illinois & .119 & .104 & .536 & .245 & .001 \\
\hline Indiana & .000 & .000 & .107 & .000 & .000 \\
\hline Iowa & .000 & .000 & .038 & .000 & .000 \\
\hline Kansas & .000 & .000 & .494 & .208 & .000 \\
\hline Mississippi & .000 & .000 & .615 & .119 & .000 \\
\hline New Mexico & .000 & .307 & .125 & .174 & .000 \\
\hline New York & .000 & .111 & .000 & .031 & .025 \\
\hline Oklahoma & .000 & .000 & .129 & .000 & .000 \\
\hline Tennessee & .000 & .000 & .109 & 1.023 & .036 \\
\hline Texas & .000 & .107 & .627 & .249 & .009 \\
\hline Wyoming & .000 & .014 & .000 & .000 & .000 \\
\hline \multirow[t]{2}{*}{ Decentralized states } & .004 & .045 & .402 & .294 & .005 \\
\hline & $(.02)$ & $(.11)$ & (.61) & $(.60)$ & $(.01)$ \\
\hline \multirow[t]{2}{*}{ Centralized states } & .001 & .035 & .129 & .008 & .000 \\
\hline & $(.01)$ & $(.07)$ & $(.21)$ & $(.03)$ & $(.00)$ \\
\hline \multirow[t]{3}{*}{ All states } & .003 & .042 & .316 & .205 & .004 \\
\hline & $(.02)$ & $(.10)$ & $(.53)$ & $(.51)$ & $(.01)$ \\
\hline & \multicolumn{5}{|c|}{ B. Within-State Variance of Tastes, $\operatorname{Var}[E(t)]$} \\
\hline Alabama & 1.517 & 1.945 & 3.408 & 10.021 & 4.652 \\
\hline California & 5.832 & 4.834 & 4.320 & 2.541 & 18.365 \\
\hline Georgia & 1.530 & 2.205 & 3.548 & 8.890 & 4.936 \\
\hline Idaho & 3.673 & 2.344 & 4.363 & 3.463 & 1.906 \\
\hline Illinois & 10.058 & 6.634 & 7.873 & 19.365 & 22.318 \\
\hline Indiana & 2.653 & 2.301 & 2.038 & 2.818 & 2.822 \\
\hline Iowa & 2.333 & 2.781 & 3.895 & 6.651 & 3.399 \\
\hline Kansas & 2.020 & 1.610 & 6.906 & 13.293 & 6.206 \\
\hline Mississippi & 2.974 & 2.385 & 4.251 & 5.921 & 4.854 \\
\hline New Mexico & 12.583 & 13.798 & 13.802 & 17.351 & 9.459 \\
\hline New York & 8.388 & 7.965 & 7.882 & 27.872 & 18.479 \\
\hline Oklahoma & .940 & .941 & .870 & 2.405 & 1.778 \\
\hline Tennessee & 1.642 & 2.185 & 3.417 & 8.680 & 4.950 \\
\hline Texas & 6.839 & 8.739 & 9.707 & 21.406 & 8.790 \\
\hline Wyoming & 9.750 & 5.308 & 13.406 & 9.041 & 5.002 \\
\hline \multirow[t]{2}{*}{ Decentralized states } & 5.332 & 5.239 & 13.279 & 28.390 & 10.437 \\
\hline & $(2.79)$ & $(3.42)$ & (21.23) & $(46.48)$ & $(5.56)$ \\
\hline \multirow[t]{2}{*}{ Centralized states } & 3.702 & 3.378 & 5.446 & 5.005 & 5.274 \\
\hline & $(2.69)$ & $(2.02)$ & $(4.36)$ & $(2.21)$ & $(4.18)$ \\
\hline \multirow[t]{2}{*}{ All states } & 4.721 & 4.619 & 10.831 & 21.082 & 8.931 \\
\hline & $(2.84)$ & $(3.13)$ & (18.06) & $(39.90)$ & (5.67) \\
\hline
\end{tabular}

NoTE. - The 15 states listed here are selected to ensure diversity in geography and state policy. In the last three rows of each panel, the listed value is the mean and the value in parentheses is the standard deviation. 
TABLE 4

Probit Estimation of State Decentralization Dependent Variable: State Is Decentralized (Indicator)

\begin{tabular}{|c|c|c|c|c|c|c|c|}
\hline & \multirow{2}{*}{$\begin{array}{l}\text { No } b \\
(1)\end{array}$} & \multirow{2}{*}{$\begin{array}{l}\text { FULL } \\
(2)\end{array}$} & \multicolumn{5}{|c|}{ SPECIFICATION } \\
\hline & & & (1) & (2) & (3) & (4) & (5) \\
\hline & \multicolumn{7}{|c|}{ A. Taste Measures } \\
\hline $\begin{array}{l}N^{-1} \min \left[\sum_{i \in D}\left|E\left(t_{i}\right)\right|,\right. \\
\left.\quad \sum_{i \in W}\left|E\left(t_{i}\right)\right|\right]\end{array}$ & $\begin{array}{l}2.063 \\
(.81)\end{array}$ & $\begin{array}{l}1.570 \\
(.65)\end{array}$ & $\begin{array}{l}1.936 \\
(.84)\end{array}$ & $\begin{array}{l}2.112 \\
(.73)\end{array}$ & $\begin{array}{l}1.890 \\
(.86)\end{array}$ & $\begin{array}{l}2.039 \\
(.69)\end{array}$ & $\begin{array}{l}1.851 \\
(.77)\end{array}$ \\
\hline \multirow[t]{2}{*}{$I\left(\sum_{i} E\left(t_{i}\right)>0\right)$} & $\begin{array}{l}.043 \\
(.15)\end{array}$ & $\begin{array}{l}.226 \\
(.49)\end{array}$ & $\begin{array}{l}-.226 \\
(.19)\end{array}$ & $\begin{array}{l}.025 \\
(.13)\end{array}$ & $\begin{array}{l}.081 \\
(.10)\end{array}$ & $\begin{array}{l}.056 \\
(.07)\end{array}$ & $\begin{array}{l}.377 \\
(.31)\end{array}$ \\
\hline & \multicolumn{7}{|c|}{ B. $b$ Measures } \\
\hline Liquor interest group & $\cdots$ & $\begin{array}{c}-.711 \\
(.36)\end{array}$ & $\begin{array}{c}-.651 \\
(.31)\end{array}$ & $\cdots$ & $\ldots$ & $\cdots$ & $\ldots$ \\
\hline Centralization ratio & $\cdots$ & $\begin{array}{c}-.624 \\
(.58)\end{array}$ & $\ldots$ & $\begin{array}{c}-.566 \\
(.41)\end{array}$ & $\ldots$ & $\cdots$ & $\ldots$ \\
\hline $\begin{array}{l}\text { Number of govern- } \\
\text { ments per } \\
\text { population }\end{array}$ & $\cdots$ & $\begin{array}{l}.014 \\
(.39)\end{array}$ & $\cdots$ & $\ldots$ & $\begin{array}{r}-.277 \\
(.23)\end{array}$ & $\cdots$ & $\ldots$ \\
\hline Poole-Rosenthal score & $\cdots$ & $\begin{array}{r}-.261 \\
(.78)\end{array}$ & $\cdots$ & $\cdots$ & $\cdots$ & $\begin{array}{c}-.212 \\
(.64)\end{array}$ & $\cdots$ \\
\hline $\begin{array}{l}\text { Motor vehicles per } \\
\text { capita }\end{array}$ & $\cdots$ & $\begin{array}{r}-1.760 \\
(1.35)\end{array}$ & $\cdots$ & $\ldots$ & $\cdots$ & $\ldots$ & $\begin{array}{r}-1.391 \\
(1.10)\end{array}$ \\
\hline Observations & 240 & 238 & 240 & 240 & 238 & 240 & 240 \\
\hline Log likelihood & -144.37 & -131.83 & -136.07 & -138.61 & -140.65 & -144.24 & -143.28 \\
\hline
\end{tabular}

NoTE.-Sample is 48 contiguous states (pooled data for 1935, 1940, 1950, 1960, and 1970). Bootstrap standard errors are in parentheses below the parameter estimates (see Sec. IVB). All specifications also include a constant.

ticular states can be striking. States that always have a centralized policy (California, Idaho, Indiana, Iowa, Oklahoma, and Wyoming) seem to have far less diverse tastes over liquor policy than states that have a decentralized policy (Illinois, New Mexico, New York, and Texas). In addition, the five remaining states in table 3 , which each adopted a decentralized policy during the sample period, seem to experience growth in the various heterogeneity measures prior to adoption (e.g., Kansas decentralized liquor policy in 1948). It would be interesting to see whether heterogeneity jumps immediately before decentralization. Unfortunately, this is not possible because the local characteristics, and thus the taste measures, are observed no more than once per decade.

Our formal tests of the model are based on generating annual measures of each state's taste distribution from the estimates in table 2 and then estimating (3) and (4). The first state decision is to decide whether to decentralize, which we model as a probit in which the dependent variable is an indicator that is one for decentralized states. The key findings are presented in table 4 , where we pool the values from the five years in the first stage. The results are consistent with our theoretical model. The positive and significant parameter on minority tastes (row 1) means that a state is more likely to decentralize when the minority decisive voters have more extreme tastes. This effect is quite large: In 
TABLE 5

Probit Estimation of State Centralized Policy Choice Dependent Variable: State Is centralized, Wet (Indicator)

\begin{tabular}{|c|c|c|c|c|c|c|}
\hline & \multirow[b]{2}{*}{ No $b$} & \multicolumn{5}{|c|}{ SPECIFICATION } \\
\hline & & (1) & (2) & (3) & (4) & (5) \\
\hline & \multicolumn{6}{|c|}{ A. Taste Measures } \\
\hline$I\left(\sum_{i} E\left(t_{i}\right)>0\right)$ & $\begin{array}{l}1.515 \\
(.46)\end{array}$ & $\begin{array}{l}1.177 \\
(.49)\end{array}$ & $\begin{array}{l}1.563 \\
(.40)\end{array}$ & $\begin{array}{l}1.495 \\
(.33)\end{array}$ & $\begin{array}{c}1.476 \\
(.39)\end{array}$ & $\begin{array}{c}1.379 \\
(.79)\end{array}$ \\
\hline \multirow[t]{2}{*}{$\begin{array}{l}N^{-1} \min \left[\sum_{i \in D}\left|E\left(t_{i}\right)\right|,\right. \\
\left.\sum_{i \in W}\left|E\left(t_{i}\right)\right|\right]\end{array}$} & $\begin{array}{r}-1.357 \\
(1.31)\end{array}$ & $\begin{array}{r}-2.099 \\
(1.41)\end{array}$ & $\begin{array}{r}-1.589 \\
(1.12)\end{array}$ & $\begin{array}{r}-1.375 \\
(1.19)\end{array}$ & $\begin{array}{r}-1.307 \\
(1.09)\end{array}$ & $\begin{array}{r}-1.563 \\
(1.20)\end{array}$ \\
\hline & \multicolumn{6}{|c|}{ B. $b$ Measures } \\
\hline $\begin{array}{l}\text { Liquor interest } \\
\text { group }\end{array}$ & $\cdots$ & $\begin{array}{c}-.866 \\
(.54)\end{array}$ & $\cdots$ & $\cdots$ & $\cdots$ & $\cdots$ \\
\hline Centralization ratio & $\cdots$ & $\ldots$ & $\begin{array}{c}.818 \\
(.91)\end{array}$ & $\cdots$ & $\cdots$ & $\cdots$ \\
\hline $\begin{array}{l}\text { Number of govern- } \\
\text { ments per } \\
\text { population }\end{array}$ & $\cdots$ & $\cdots$ & $\ldots$ & $\begin{array}{c}-.033 \\
(.31)\end{array}$ & $\cdots$ & $\cdots$ \\
\hline $\begin{array}{l}\text { Poole-Rosenthal } \\
\text { score }\end{array}$ & $\cdots$ & $\cdots$ & $\cdots$ & $\cdots$ & $\begin{array}{r}.362 \\
(1.16)\end{array}$ & $\cdots$ \\
\hline $\begin{array}{l}\text { Motor vehicles per } \\
\text { capita }\end{array}$ & $\cdots$ & $\cdots$ & $\cdots$ & $\cdots$ & $\cdots$ & $\begin{array}{c}6.934 \\
(4.21)\end{array}$ \\
\hline Observations & 78 & 78 & 78 & 76 & 78 & 78 \\
\hline Log likelihood & -27.63 & -25.16 & -27.06 & -27.59 & -27.55 & -25.79 \\
\hline
\end{tabular}

the full specification (col. 2), a one-standard-deviation increase in the minority group's willingness to "buy" decentralization increases the probability that a state is decentralized by .556 (evaluated at mean sample values). Also, as predicted, the mean taste term (row 2) does not have a significant influence on the decision to decentralize.

Our measures of the relative benefit of centralization $b$ (panel B) are also generally consistent with the theoretical model. In particular, our preferred measure, the strength of the liquor interest group (row 3), is associated with a lower probability of decentralization and is statistically significant. Notice that omitting our admittedly imperfect $b$ measures does not diminish the strong positive effect of taste heterogeneity (col. 1).

The second state decision, which is conditional on centralization, is to pick a uniform wet or dry policy. Table 5 contains the results of a probit analysis among centralized states in which the dependent variable is an indicator that is one for wet states. These results are also consistent with our model. States in which the mean county is wet (row 1) are more likely to select a wet policy. As predicted, the minority group's willingness to "buy" decentralization (row 2) and the centralization benefit measures (panel B) have insignificant parameters. 
To see whether the results are driven by a single period, we reestimated the specifications in tables 4 and 5 (i) including year dummies in the pooled sample and (ii) separately for each year. The parameters on minority tastes and the $b$ proxies maintain their sign and statistical significance. ${ }^{21}$ Also, for roughly two-thirds of the specifications, it is not possible to reject with 95 percent confidence the null that the parameters on all the year dummies are identical. ${ }^{22}$ This is interesting given that table 3 indicates that liquor tastes vary over time.

\section{Robustness Tests}

Our results are robust to several alternative approaches. For the firststage estimates of local liquor tastes (table 2), we conduct five different robustness tests. First, we investigate the role of taxes, because it is possible that counties might adopt a wet policy to collect revenues. In practice, these incentives are quite small because most states allocate the lion's share of tax revenue independently of a county's liquor status. Even dry counties typically receive liquor revenue. On average, a county will gain well under $\$ 5.00$ per capita in tax revenues from being wet. More formal evidence also suggests that taxes do not drive policy outcomes. ${ }^{23}$ Second, we add country of origin variables to the list of firststage covariates (these variables might reflect cultural attitudes toward liquor policy not captured by the other explanatory variables). For the available years (1935 and 1940), many country of origin variables have significant parameters, but our state-level taste variables are quite similar to those found using our original specification. Third, to more generally investigate the role of omitted covariates in the first stage, we pool all years of data and estimate a conditional fixed-effects logit. The same basic relationship between tastes and state policies in tables 4 and 5 holds when the fixed-effects parameters are used to generate estimated tastes. Fourth, we reestimate the first stage after excluding the strategic

\footnotetext{
${ }^{21}$ It is difficult to estimate year-by-year specifications for the conditional centralized policy probits (table 5) because our mean wet taste indicator, $I\left(\sum_{i} E\left(t_{i}\right)>0\right)$, perfectly predicts the dependent variable in 1950 and predicts all but one state in 1935 and 1940. This is precisely what the theory leads us to expect.

${ }^{22}$ In the conditional centralized probits (table 5), it is not possible to estimate a year dummy for 1970 since no state is centralized dry in that year. It is also typically not possible to compute the standard error on the 1960 year dummy because only one state has a centralized dry policy in that year.

${ }^{23}$ Liquor taxes cannot be directly included in the first stage because county-level data are unavailable. Instead we reestimate the first-stage parameters for counties in which there is virtually no tax benefit of being wet (these counties are in states in which the "local share" of liquor tax revenues is 5 percent or less). For all years but 1950, it is not possible to reject the null that the parameters are identical to those from the full sample. In addition, the state fixed effects in table 2 should account for the incentives any state tax system imparts on the local policy decision. Finally, the "local share" of liquor taxes never has a statistically significant effect in a state-level decentralization probit.
} 
interaction and spatial error correlation terms as well as the centralized neighbor indicators. This omission does not qualitatively change our imputed state-level taste variables. Fifth, we restrict the first-stage sample in 1940-70 to include only counties in states that were decentralized in 1935 to investigate the possible effects of dynamic sample selection. This does not noticeably change the parameter estimates.

We also consider the robustness of the second-stage state-level estimates (tables 4 and 5) in various ways. First, we reestimate the parameters using various subsets of the data: omitting various groups of states (southern states, western states, decentralized states in 1935, or random samples of 10 states) and omitting data from 1935. All the taste parameters maintain their sign and significance. Similarly, the parameters of interest do not noticeably change when we estimate second-stage specifications, which include various control variables (such as the population percentage of blacks and urban dwellers) and allow for strategic interaction between states.

Second, we investigate the possibility that our first-stage taste estimates are imperfect because of omitted variable bias. This could cause serious problems for our second-stage parameter estimates because our measure of heterogeneity is a highly nonlinear function of tastes. Therefore, we consider an alternative measure of heterogeneity, the within-state variance of local tastes (see panel B of table 3). This measure yields unbiased second-stage parameters even when there are omitted first-stage covariates (proof available on request). Intuitively, the variance is strongly separable, so the omitted portion of tastes is simply added to the secondstage error. ${ }^{24}$ We reestimate the second-stage specifications in tables 4 and 5 using as our taste measures the within-state variance and the absolute value of the mean taste. The latter is used because minority groups are unlikely to be important in states with a strong wet or dry tilt. In the decentralization probit, the taste variance has a significant, positive parameter. The absolute value of the mean has the expected negative sign, though its parameter is typically insignificant. In probits explaining centralized states' choice of wet and dry policies, a larger mean taste (level, not absolute value) increases the propensity to adopt a wet policy, whereas a higher variance has no statistically significant effect. All these estimates are consistent with the theoretical model. ${ }^{25}$

Third, we consider an alternative measure of the state taste distri-

${ }^{24}$ There is an additional rationale for considering this variance measure of heterogeneity. In the theoretical model, tastes are scaled in such a way that $t \geq 0$ indicates a preference for legalizing liquor. As the empirically estimated tastes are derived from a nonlinear estimation procedure, they need not share this property. In contrast, the variance is relatively insensitive to scaling.

${ }^{25}$ We also find similar results when we use the interquartile difference and median of the state taste distribution as our two summary statistics for local tastes. These variables have the advantage of not being strongly influenced by outliers. 
bution. It is possible that counties with a larger population have more representatives in the state legislature and so should receive more weight in defining the state taste distribution. We therefore weight each county's fitted taste value by its relative population share in the state. As a consequence, our state taste distributions change significantly. However, none of our second-stage parameters change their sign or significance.

Fourth, we consider an alternative approach to testing the theoretical model. Rather than estimating a first stage, we directly use the variance of county-level characteristics within each state as the preference heterogeneity measure. We generate the variance matrix of several variables likely to be associated with legalizing liquor and the negative of others likely to be associated with prohibiting liquor. The larger this matrix is for a given state, the more heterogeneous liquor tastes are. ${ }^{26}$ We find that two measures of the size of the variance matrix-the maximum eigenvalue norm and the sum of all elements-have a positive effect on the probability that a state is decentralized. This result is also consistent with the theoretical model.

Finally, we evaluate an alternative theory of policy selection: States and localities simply revert to their preprohibition policies when prohibition ended. While such a theory could still be taste driven, it would imply that historical inertia alone can explain liquor policies. To test this, we compare each state and county's liquor policy in 1935 with its policy in 1919, 1915, 1905, and 1890. It is possible to reject a null of simple reversion at the 95 percent confidence level for all decisions.

\section{Application: Policy Endogeneity Bias}

The estimated taste variables can be used to get more precise measures of the price elasticity of aggregate liquor consumption, an important input in determining the appropriate liquor tax rate. Most papers in this literature identify price elasticities from interstate differences in prices, which in turn are chiefly due to differences in state tax rates (Grossman et al. 1993). Without a proper taste control, this approach can lead to a spurious negative correlation between prices and consumption. Strong antiliquor sentiment may lead a state to adopt higher liquor taxes (and thus prices) and can independently lead to lower liquor consumption. One approach is to control for these taste differences through state and period fixed effects (Baltagi and Griffin 1995). However, by definition, fixed effects cannot capture state-specific dy-

\footnotetext{
${ }^{26}$ The signing convention ensures that if the off-diagonal element $(i, j)$ is large, then a county with extreme wet tastes on variable $i$ is also likely to have extreme wet tastes on variable $j$.
} 
TABLE 6

Price Elasticity of LiQuor Consumption $(N=480)$ Dependent Variable: $\ln$ (State Liquor Consumption per Capita)

\begin{tabular}{|c|c|c|c|}
\hline & \multicolumn{2}{|c|}{ ORDINARY LEAST SQUARES } & \multirow{2}{*}{$\begin{array}{c}\text { Two-STAGE } \\
\text { LEAST } \\
\text { SQUARES } \\
(3)\end{array}$} \\
\hline & (1) & (2) & \\
\hline $\ln (P)$ & $\begin{array}{c}-.703 \\
(.19)\end{array}$ & $\begin{array}{c}-.571 \\
(.20)\end{array}$ & $\begin{array}{c}-.589 \\
(.41)\end{array}$ \\
\hline$E\left(t_{s}\right)$ & $\ldots$ & $\begin{array}{l}.049 \\
(.01)\end{array}$ & $\begin{array}{l}.051 \\
(.01)\end{array}$ \\
\hline Controls? & yes & yes & yes \\
\hline State fixed effects? & yes & yes & yes \\
\hline Year fixed effects? & yes & yes & yes \\
\hline$R^{2}$ & .98 & .98 & .98 \\
\hline
\end{tabular}

NoTE.-Sample is license states for 1954-70 (monopoly states are excluded). The liquor consumption (in cases) and pretax price (per gallon) data come from Jobson Associates (various years), and the state plus federal tax (per gallon) data come from the Distilled Spirits Institute (1940-70). The price and tax terms were converted to real terms using the whiskey at home consumer price index. The price variable is the weighted price of blend, straight, bond, scotch, the Canadian, gin, run, brandy, ar The control van, and \%black. The 2SLS estimate instruments for price using the variance of the state taste distribution in addition to the mean taste and the control variables. Huber/robust/sandwich standard errors are in parentheses below the parameter estimates.

namics in tastes. A state in which there is growing sentiment for prohibition relative to other states is more likely to increase tax rates and decrease consumption. We shall explicitly control for state tastes using the estimates from the previous section. The system to be estimated is

$$
\begin{aligned}
C_{S} & =\delta_{0}+\delta_{1} P_{S}+\delta_{2} E\left(t_{S}\right)+\delta_{3} Z_{1 S}+\epsilon_{1 S}, \\
P_{S} & =\gamma_{0}+\gamma_{1} E\left(t_{S}\right)+\gamma_{2} Z_{2 S}+\epsilon_{2 S},
\end{aligned}
$$

where $C_{S}$ is per capita liquor consumption in state $S, P_{S}$ is the after-tax liquor price, $E\left(t_{S}\right)$ is the mean state preference for legalizing liquor (estimated in the previous section), $Z_{i}$ are control variables, and $\epsilon_{i}$ are possibly correlated error terms.

The results in table 6 provide support for the arguments in the previous paragraph. Omitting the mean taste term from the consumption equation (col. 1) results in a more negative price elasticity than when it is included (col. 2); this result is robust to two-stage least-squares (2SLS) estimation, which accounts for correlation between the error terms in (9) (col. 3). The intuition is that stronger tastes for legalizing liquor result in higher consumption as well as lower prices, ${ }^{27}$ so sup-

\footnotetext{
${ }^{27}$ The first-stage estimation in which the dependent variable is the logarithm of price has a parameter of -0.011 on the mean taste term (the robust $t$-statistic is -4.21 ). This equation includes the control variables listed in the note to table 6 as well as state and year fixed effects.
} 
pressing the taste term in the consumption equation biases the price parameter. $^{28}$

\section{Conclusion}

In this paper we have traced the endogeneity of liquor control policies in the United States. We argue that a state's choice of whether or not to decentralize liquor control is related to the degree of preference heterogeneity, and we have found empirical support for this conclusion using a rich data set over the period 1934-70. The logic underlying the economic theory of federalism appears to drive actual policy choices. We have also found that changes in tastes are reflected in changes in institutions: as pro-prohibition groups adopted a more liberal attitude toward liquor, states removed centralized prohibition policies. Our model of endogenous decentralization could be applied to other policy areas. For example, it would be interesting to investigate to what extent the devolution of welfare policy in the United States was driven by increases in preference heterogeneity.

Our results also highlight the importance of explicitly accounting for policy or institutional endogeneity in empirical work. As our estimates of the price elasticity of liquor demand show, ignoring policy endogeneity will typically result in biased parameter estimates. To control for such endogeneity, we employ fixed effects and imputed tastes. While the former control for time-invariant, unobserved heterogeneity, the latter help account for relative preference changes across the observational units. Policy endogeneity also has broader implications. For example, our results suggest that measuring the efficacy of a policy on the basis of the experience of a few "pioneer" states is inappropriate. Such states are likely to have a unique set of characteristics that influence both why they implemented the policy and what their outcome was.

\section{Appendix}

\section{Proof of the Proposition}

The proof will proceed by first comparing the three possible pairwise votes in the legislature and then using these results to find the Condorcet winner for any arbitrary distribution of tastes. First consider the pairwise votes involving the decentralized outcome, $C=0$. Since members cannot sell their decentralized decision, the $W$ members will all have $P_{i}=1$ and the $D$ members will all have $P_{i}=-1$ under decentralization.

Lemma 1. (1) When the legislature votes over the centralized policy $C=1$,

${ }^{28}$ More formally, if the taste term is omitted from the consumption equation in (9), the error term becomes $v_{S} \equiv \delta_{2} E\left(t_{S}\right)+\epsilon_{1 S}$. Even if the error terms are orthogonal, the price elasticity is biased since $\operatorname{Cov}\left(P_{S}, v_{S}\right)=\gamma_{1} \delta_{2} E\left(t_{S}\right)^{2} \neq 0$. Since empirically $\gamma_{1}<0, \delta_{2}>$ 0 , and $\delta_{1}<0$, the estimated price elasticity will have a negative bias. 
$P=1$ and the decentralized policy $C=0$, it will choose $C=0$ when $-N b+$ $\sum_{i \in D} 2\left|t_{i}\right| \geq 0$ and $C=1, P=1$ otherwise. (2) When the legislature votes over the centralized policy $C=1, P=-1$ and the decentralized policy $C=0$, it will choose $C=0$ when $-N b+\sum_{i \in W} 2 t_{i} \geq 0$ and $C=1, P=-1$ otherwise.

We shall focus on the first vote between $C=0$ and $C=1, P=1$ (the proof for the other vote is analogous). It will be useful to split the $D$ 's among two subgroups: denote the members with $t_{i} \in[-b / 2,0)$ as $M D$ (for moderate $D$ ) and those with $t_{i}<-b / 2$ as $E D$ (for extreme $D$ ). The main distinction between these subgroups is that the $M D$ members prefer $C=1, P=1$ to $C=0$ since $b / 2$ outweighs their relatively weak taste for policy $P=-1$. Hence, in the vote both the $W$ and the $M D$ members will support $C=1, P=1$ and the $E D$ members prefer $C=0$. First suppose that the $W$ plus $M D$ members have a numerical majority of $M$ members, so the outcome without vote trades is $C=1, P=1$. To change this outcome, the $E D$ members must bribe at least $L \geq M$ members of the majority to change their vote (we shall interchangeably refer to $L$ as a set and the cardinality of that set). To be concrete, say that $J M D$ members and $L-J W$ members are bribed. The $E D$ members are willing to pay up to $\sum_{i \in E D}\left(2\left|t_{i}\right|-b\right)$, their increase in utility from $C=0$ relative to $C=1, P=1$, and the unbribed $M D$ members will pay a counterbribe up to $\sum_{i \in M D \backslash J}\left(b-2\left|t_{i}\right|\right)$ and the unbribed $W$ members will pay a counterbribe up to $\sum_{i \in W \backslash(L-J)} b$ (to derive the latter value, recall that the $W$ members get their preferred policy $P=1$ regardless of the vote outcome). The net change in utility of the $L$ bribed members from selling their votes is

$$
\begin{aligned}
\Delta U_{L}^{\mathrm{bribe}}= & {\left[\sum_{i \in J}\left(2\left|t_{i}\right|-b\right)-\sum_{i \in L^{-} J} b\right]+\left[\sum_{i \in E D}\left(2\left|t_{i}\right|-b\right)\right] } \\
& -\left[\sum_{i \in M D / J}\left(b-2\left|t_{i}\right|\right)+\sum_{i \in W /\left(L^{-} J\right)} b\right],
\end{aligned}
$$

where the first term in brackets represents the bribees' loss in utility from getting their less preferred outcome and the other two brackets represent the maximum value of the bribe and the forgone counterbribe. A bit of algebra shows that

$$
\Delta U_{L}^{\text {bribe }}=-N b+\sum_{i \in D} 2\left|t_{i}\right| .
$$

The ED's will be able to buy the votes for $C=0$ if and only if (A2) is nonnegative. Now suppose that the $E D$ members have a numerical majority, and so the outcome without vote trades is $C=0$. When the $M D$ 's and $W$ s try to bribe enough $E D$ 's to change the outcome to $C=1, P=1$, similar algebra shows that the change in utility of the bribees from selling their vote is $\Delta U_{L}^{\text {bribe }}=N b-$ $\sum_{i \in D} 2\left|t_{i}\right|$. This means that the condition for decentralization is identical to the case in which the $E D$ members are a numerical minority.

The second pairwise vote involves the choice between the two centralized policies, $C=1, P=1$ and $C=1, P=-1$.

Lemma 2. When the legislature votes over the two centralized policy outcomes, $C=1, P=1$ will be chosen when $\sum_{i} t_{i} \geq 0$ and $C=1, P=-1$ will be chosen when $\sum_{i} t_{i}<0$.

To see this result, we shall assume that $\sum_{i} t_{i} \geq 0$ (the proof for $\sum_{i} t_{i}<0$ follows from simply interchanging the groups and the outcomes). In this vote, all $W$ members prefer $C=1, P=1$ and the $D$ members prefer $C=1, P=-1$. Assume first that the majority of members are $W$, with $M$ the size of their numerical 
advantage. In the absence of transfers, the outcome is $C=1, P=1$, and in this case it is not possible for the $D$ members to generate a large enough transfer to change the outcome. To see this, suppose that the $D$ 's try to bribe $L \geq M W$ members to vote for $C=1, P=-1$ in order to change the majority rule outcome. The maximum transfer that the $D$ 's are willing to pay is $\sum_{i \in D} 2\left|t_{i}\right|$, their increase in utility from $C=1, P=-1$ relative to $C=1, P=1$; the unbribed $W$ s are willing to offer a counterbribe of $\sum_{i \in W \backslash L} 2 t_{i}$. The net utility to the $L$ members from accepting the bribe is

$$
\Delta U_{L}^{\text {bribe }}=-\sum_{i \in L} 2 t_{i}+\sum_{i \in D} 2\left|t_{i}\right|-\sum_{i \in W / L} 2 t_{i} \leq 0
$$

where the first term represents the bribees' loss in utility from getting their less preferred outcome $C=1, P=-1$, the second term is the maximum bribe from the $D$ 's, and the third term is the loss of the maximum counterbribe from the remaining $W \mathrm{~s}$. Since this expression equals $-2 \sum_{i} t_{i}$, which is weakly negative, the $L$ members refuse to sell their votes. Suppose instead that the majority of members are $D$, with $M$ the size of their numerical advantage. In this case the $W$ members are willing to pay a bribe of $\sum_{i \in W} 2 t_{i}$ to any set $L \geq M$ of $D$ members to vote for $C=1, P=1$, and the unbribed $D$ members will pay a counterbribe of $\sum_{i \in D \backslash L} 2\left|t_{i}\right|$. Because the $L$ bribed $D$ members will lose utility $\sum_{i \in L} 2\left|t_{i}\right|$ by voting for $C=1, P=1$, their net change in utility from accepting the bribe is

$$
\Delta U_{L}^{\text {bribe }}=-\sum_{i \in L} 2\left|t_{i}\right|+\sum_{i \in W} 2 t_{i}-\sum_{i \in D / L} 2\left|t_{i}\right| \geq 0,
$$

where we have again considered the maximum possible bribes. This shows that the $W$ members are able to offer a large enough bribe to earn the $C=1$, $P=1$ outcome.

The final step in the proof is to consider the simultaneous vote over the three outcomes. We focus on the case in which $\sum_{i} t_{i} \geq 0$ (the proof for $\sum_{i} t_{i}<0$ is analogous). Here $C=1, P=1$ defeats $C=1, P=-1$ (from lemma 2). If $-N b+\sum_{i \in D} 2\left|t_{i}\right|<0$, then $C=1, P=1$ also defeats $C=0$ (from lemma 1), and so it is the Condorcet winner. Alternatively, if $-N b+\sum_{i \in D} 2\left|t_{i}\right| \geq 0$, then $C=0$ defeats $C=1, P=1$ (from lemma 1) and also $C=1, P=-1$ (since $\sum_{i \in W} t_{i} \geq$ $\sum_{i \in D}\left|t_{i}\right|$ and from lemma 1$)$, and so it is the Condorcet winner.

\section{References}

Angeles, Gustavo; Guilkey, David K.; and Mroz, Thomas A. "Purposive Program Placement and the Estimation of Family Planning Program Effects in Tanzania." J. American Statis. Assoc. 93 (September 1998): 884-99.

Anselin, Luc. Spatial Econometrics: Methods and Models. Dordrecht: Kluwer, 1988. Baltagi, Badi H., and Griffin, James M. "A Dynamic Demand Model for Liquor: The Case for Pooling.” Rev. Econ. Statis. 77 (August 1995): 545-54.

Besley, Timothy, and Case, Anne. "Unnatural Experiments? Estimating the Incidence of Endogenous Policies." Working Paper no. 4956. Cambridge, Mass.: NBER, December 1994.

Besley, Timothy, and Coate, Stephen. "Centralized versus Decentralized Provision of Local Public Goods: A Political Economy Analysis.” Working Paper no. 7084. Cambridge, Mass.: NBER, April 1999.

Brown, Robert W.; Jewell, R. Todd; and Richer, Jerrell. "Endogenous Alcohol Prohibition and Drunk Driving." Southern Econ. J. 62 (April 1996): 1043-53.

Chaloupka, Frank J.; Saffer, Henry; and Grossman, Michael. "Alcohol Control 
Policies and Motor Vehicle Fatalities." J. Legal Studies 22 (January 1993): 161-86.

Dillinger, William. "Decentralization and Its Implications for Urban Service Delivery." Urban Management and Municipal Finance Discussion Paper no. 16. Washington: World Bank, 1994.

Distilled Spirits Institute. Annual Statistical Review of the Distilled Spirits Industry. Washington: Distilled Spirits Inst., Res. and Statis. Div., 1940-70.

Dobyns, Fletcher. The Amazing Story of Repeal: An Exposé of the Power of Propaganda. Chicago: Willett, Clark, 1940.

Efron, Bradley, and Tibshirani, Robert J. An Introduction to the Bootstrap. New York: Chapman \& Hall, 1993.

Frey, Bruno S., and Eichenberger, Reiner. The New Democratic Federalism for Europe: Functional, Overlapping, and Competing Jurisdictions. Cheltenham, U.K.: Elgar, 1999.

Gebhart, John C. "Movement against Prohibition." Ann. American Acad. Polit. and Soc. Sci. 163 (September 1932): 172-80.

General Social Survey. GSS 1972-1996 Cumulative Datafile. Survey Documentation and Analysis Archive. http://csa.berkeley.edu:7502/archive.htm, 1999.

Goff, Brian, and Anderson, Gary. "The Political Economy of Prohibition in the United States, 1919-1933.” Soc. Sci. Q. 75 (June 1994): 270-83.

Grossman, Michael; Sindelar, Jody L.; Mullahy, John; and Anderson, Richard. "Policy Watch: Alcohol and Cigarette Taxes." J. Econ. Perspectives 7 (Autumn 1993): 211-22.

Gründler, Johannes. Lexikon der Christlichen Kirchen und Sekten unter Berücksichtigung der Missionsgesellschaften. 2 vols. Vienna: Herder, 1961.

Harrison, Leonard V., and Laine, Elizabeth. After Repeal: A Study of Liquor Control Administration. New York: Harper \& Brothers, 1936.

Hersch, Philip L., and Netter, Jeffry M. "State Prohibition of Alcohol: An Application of Diffusion Analysis to Regulation." In Research in Law and Economics, vol. 12, edited by Richard O. Zerbe. Greenwich, Conn.: JAI, 1989.

Hoover, Gary A. "The Political Economy of Liquor License Distribution in the City of St. Louis." Manuscript. Tuscaloosa: Univ. Alabama, 1999.

Hsiao, Cheng. Analysis of Panel Data. New York: Cambridge Univ. Press, 1986.

Inman, Robert P., and Rubinfeld, Daniel L. "Rethinking Federalism." J. Econ. Perspectives 11 (Fall 1997): 43-64.

Kenkel, Donald S. "Drinking, Driving, and Deterrence: The Effectiveness and Social Costs of Alternative Policies." J. Law and Econ. 36 (October 1993): 877-913.

Kyvig, David E. Repealing National Prohibition. Chicago: Univ. Chicago Press, 1979. Munger, Michael, and Schaller, Thomas. "The Prohibition-Repeal Amendments: A Natural Experiment in Interest Group Influence.” Public Choice 90 (March 1997): 139-63.

Oates, Wallace E. Fiscal Federalism. New York: Harcourt, Brace, Jovanovich, 1972. . "An Essay on Fiscal Federalism.” J. Econ. Literature 37 (September 1999): 1120-49.

Odegard, Peter H. Pressure Politics: The Story of the Anti-saloon League. New York: Columbia Univ. Press, 1928.

Olson, Mancur. The Logic of Collective Action: Public Goods and the Theory of Groups. Cambridge, Mass.: Harvard Univ. Press, 1965.

Pagan, Adrian R. "Econometric Issues in the Analysis of Regressions with Generated Regressors." Internat. Econ. Rev. 25 (February 1984): 221-47. 
Poirier, Dale J., and Ruud, Paul A. "Probit with Dependent Observations." Rev. Econ. Studies 55 (October 1988): 593-614.

Poole, Keith T., and Rosenthal, Howard. Congress: A Political-Economic History of Roll Call Voting. New York: Oxford Univ. Press, 1997.

Ruhm, Christopher J. "Alcohol Policies and Highway Vehicle Fatalities." J. Health Econ. 15 (August 1996): 435-54.

Smith, Janet Kiholm. "An Analysis of State Regulations Governing Liquor Store Licensees." J. Law and Econ. 25 (October 1982): 301-19.

Strumpf, Koleman S., and Oberholzer-Gee, Felix. "Local Liquor Control from 1934 to 1970." In Public Choice Interpretations of American Economic History, edited by Jac C. Heckelman, John C. Moorhouse, and Robert M. Whaples. Boston: Kluwer, 2000.

Toma, Eugenia Froedge. "State Liquor Licensing, Implicit Contracting, and Dry/ Wet Counties." Econ. Inquiry 26 (July 1988): 507-24.

Wooddy, Carroll H. The Growth of Federal Government, 1915-1932. New York: McGraw-Hill, 1934. 